Article

\title{
Synthesis and Neuroprotective Action of Xyloketal Derivatives in Parkinson's Disease Models
}

\section{Shichang Li ${ }^{1}$, Cunzhou Shen ${ }^{2}$, Wenyuan Guo ${ }^{2}$, Xuefei Zhang ${ }^{1}$, Shixin Liu ${ }^{1}$, Fengyin Liang ${ }^{2}$, Zhongliang Xu ${ }^{1}$, Zhong Pei ${ }^{2}$, Huacan Song ${ }^{1, *}$, Liqin Qiu ${ }^{1}$, Yongcheng Lin ${ }^{1}$ and Jiyan Pang ${ }^{1, *}$}

1 School of Chemistry \& Chemical Engineering, Sun Yat-Sen University, No. 135 Xingangxi Road, Guangzhou 510275, China; E-Mails: lishich@mail2.sysu.edu.cn (S.L.); zhxuefei@mail2.sysu.edu.cn (X.Z.); 1sxinhoho@gmail.com (S.L.); xzhliang1979@163.com (Z.X.); qiuliqin@mail.sysu.edu.cn (L.Q.); ceslyc@mail.sysu.edu.cn (Y.L.)

2 Department of Neurology, The First Affiliated Hospital, Sun Yat-Sen University, No. 58 Zhongshan Road II, Guangzhou 510080, China; E-Mails: sczmc39@sina.com (C.S.); guoweny@mail2.sysu.edu.cn (W.G.); liangfy@mail2.sysu.edu.cn (F.L.); peizhong@yahoo.com (Z.P.)

* Author to whom correspondence should be addressed; E-Mail: yjhxhc@mail.sysu.edu.cn (H.S.); cespjy@mail.sysu.edu.cn (J.P.); Tel.: +86-20-84110918 (H.S.); Fax: +86-20-84112245 (H.S.); Tel./Fax: +86-20-84036554 (J.P.).

Received: 1 November 2013; in revised form: 2 December 2013 / Accepted: 4 December 2013 / Published: 18 December 2013

\begin{abstract}
Parkinson's disease (PD) is the second most common neurodegenerative disease affecting people over age 55. Oxidative stress actively participates in the dopaminergic (DA) neuron degeneration of PD. Xyloketals are a series of natural compounds from marine mangrove fungus strain No. 2508 that have been reported to protect against neurotoxicity through their antioxidant properties. However, their protection versus 1-methyl-4-phenylpyridinium (MPP+)-induced neurotoxicity is only modest, and appropriate structural modifications are necessary to discover better candidates for treating PD. In this work, we designed and synthesized 39 novel xyloketal derivatives (1-39) in addition to the previously reported compound, xyloketal $B$. The neuroprotective activities of all 40 compounds were evaluated in vivo via respiratory burst assays and longevity-extending assays. During the zebrafish respiratory burst assay, compounds $\mathbf{1}, \mathbf{9}$, 23, 24, 36 and 39 strongly attenuated reactive oxygen species (ROS) generation at $50 \mu \mathrm{M}$. In the Caenorhabditis elegans longevity-extending assay, compounds 1, 8, 15, 16 and 36 significantly extended the survival rates $(p<0.005 v s$. dimethyl sulfoxide (DMSO)). A
\end{abstract}


total of 15 compounds were tested for the treatment of Parkinson's disease using the MPP+-induced C. elegans model, and compounds $\mathbf{1}$ and $\mathbf{8}$ exhibited the highest activities $\left(p<0.005 v s . \mathrm{MPP}^{+}\right)$. In the MPP+-induced C57BL/6 mouse PD model, $40 \mathrm{mg} / \mathrm{kg}$ of 1 and 8 protected against MPP+-induced dopaminergic neurodegeneration and increased the number of DA neurons from $53 \%$ for the $\mathrm{MPP}+$ group to $78 \%$ and $74 \%$, respectively $(p<0.001$ vs. MPP+ group). Thus, these derivatives are novel candidates for the treatment of PD.

Keywords: xyloketal; Caenorhabditis elegans; zebrafish; C57BL/6; Parkinson's disease

\begin{abstract}
Abbreviations
PD, Parkinson's disease; DA, dopaminergic; C. elegans, Caenorhabditis elegans; ROS, reactive oxygen species; PMA, phorbol myristate acetate; DCF, dichlorofluorescein; DMSO, dimethyl sulfoxide; $\mathrm{H}_{2}$ DCFDA, 2',7'-dihydrodichlorofluorescein diacetate; DCM, dichloromethane; MPP+, 1-methyl-4-phenylpyridinium; MPTP, 1-methyl-4-phenyl-1,2,3,6-tetrahydropyridine; hpf, hours post-fertilization; BOP, (benzotriazol-1-yloxy)tris(dimethylamino)phosphonium hexafluorophosphate; DIEA, $N, N$-diisopropylethylamine; GFP, green fluorescent protein; NADPH, triphosphopyridine nucleotide; ex., excitation; em., emission; ADE, anterior deirid; CEP, cephalic; LSD, Fisher's least significant difference; EI, electron ionization; HR, high resolution; calcd., calculated; CCD, charge-coupled-device.
\end{abstract}

\title{
1. Introduction
}

Parkinson's disease (PD), the second most common neurodegenerative disease, affects a large number of people and has a mean onset age of 55, and the incidence increases with age. Substantial evidence has demonstrated that mitochondrial dysfunction and the consequent oxidative stress, including oxidation of dopamine species, initially provokes this neurodegeneration [1,2]. Oxidative stress can damage lipids, proteins and DNA [3,4] and induce Lewy Body (LB) protein aggregation [5]. Therefore, blocking oxidative stress is one strategy for treating PD. Coenzyme Q10 (CoQ10) is a natural antioxidant that has been isolated and assessed for its effect on PD [6,7]. Many of the neurotoxins involved in PD, such as 6-hydroxydopamine (6-OHDA), 1-methyl-4-phenyl-1,2, 3,6-tetrahydropyridine (MPTP), paraquat and rotenone [8-11], induce neurodegeneration via the formation of reactive oxygen species (ROS). Of these compounds, MPTP, which is metabolized to the active 1-methyl-4-phenylpyridinium (MPP+), has been widely used in toxin-induced PD models, because it can induce parkinsonian syndrome with all of the characteristic features of PD [12-14].

Model organisms, such as zebrafish, C. elegans, yeast and drosophila melanogaster, are powerful tools in drug screening and signaling research [15] because of their short lifecycles, availability and low costs. More importantly, using whole organisms provides more insight into the biological processes of mammalian diseases than in vitro models. Zebrafish respiratory burst assays are an ROS assay based on the activity of NADPH oxidase. Juglone can produce ROS that induce mitochondrial 
dysfunction and cause mitochondrial membrane potential loss during C. elegans longevity-extending assays $[16,17]$. These two assays are often used for the high-throughput screening of compounds and the in vivo identification of therapeutic targets [18,19].

Marine environments are rich sources of novel and unusual secondary metabolites, many of which show considerable promise as therapeutic agents. However, most of these compounds are stereochemically complex or have low activity. To develop chemically simple and active candidates, appropriate structural modifications are important. Xyloketals are a series of novel natural compounds from marine mangrove fungi (Chart 1) [20-24]. We previously demonstrated that xyloketal B showed protection in different cell models and can protect against MPP+-induced neurotoxicity via its antioxidant properties [25-28]. Considering their remarkable structural and biological properties, the stereoselective synthesis of xyloketals has attracted much interest because of their unique bicyclic acetal moieties fused to their aromatic core structure [29-37]. Although xyloketal B displays good in vitro antioxidative activity, its protective action against neural cell injury is moderate, and its effects in PD treatment remain unproven. Moreover, the structure of xyloketal B (Chart 1), which contains six asymmetric carbons at the 2, 2',5, 5', 6 and $6^{\prime}$ positions, renders its asymmetric synthesis and modification difficult. Therefore, we have become keenly interested in designing and synthesizing novel analogues of xyloketal B to overcome its shortcomings, improve its activity and discover potential candidates for treating PD. In this paper, we describe the design, synthesis, biological evaluation using multiple models and structure-activity relationship (SAR) of 39 new xyloketal derivatives (1-39) and the previously reported xyloketal B (Xyl-B) [37]. The modifications to xyloketal $\mathrm{B}$ focus on expanding the tetrahydrofuran ring into a tetrahydropyran ring and adding substituents to the 12- and 13-positions of the aromatic ring (Chart 2). The antioxidant activities of all 40 compounds were evaluated in oxidative models using zebrafish [38] and C. elegans [17]. The neuroprotective activities of any compound with high antioxidative actions were further investigated using MPP+-induced PD models [19,27], including the C. elegans and C57BL/6 mouse models [39], to evaluate their ability to protect against dopaminergic neuron degeneration.

Chart 1. Structure of naturally isolated xyloketals A-H.
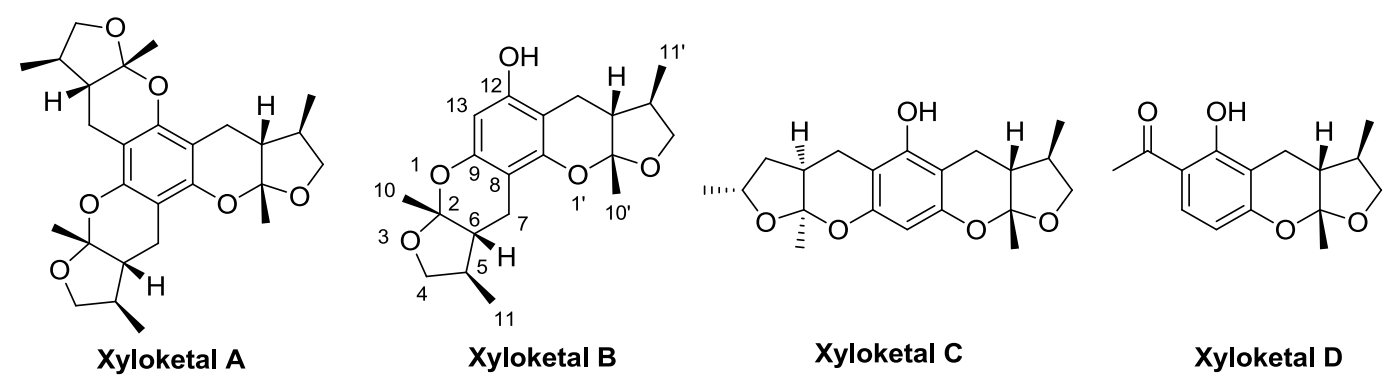

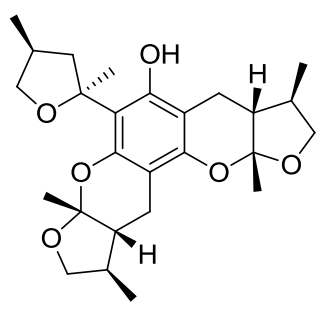

Xyloketal E

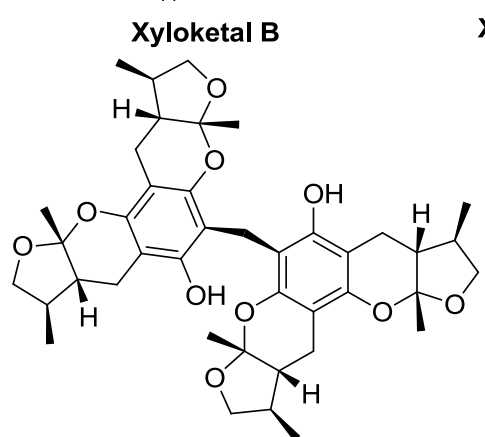

Xyloketal F
Xyloketal C<smiles>CC(=O)c1cc2c(cc1O)O[C@H](C)CC2</smiles>

Xyloketal D

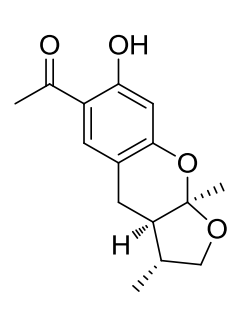

Xyloketal G
Xyloketal H 
Chart 2. Modifications of xyloketal B.

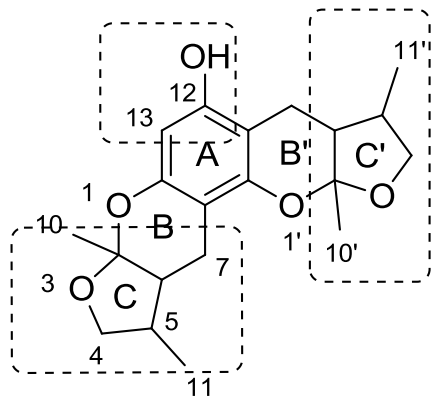

Xyloketal B (Xyl-B)

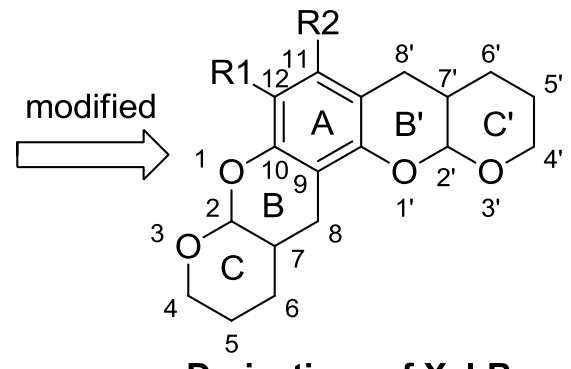

Derivatives of XyI-B

\section{Results and Discussion}

\subsection{Chemistry}

The synthetic routes to 1-39 are shown in Schemes 1-3, and all new compounds were fully characterized by MS and NMR. The syntheses were performed in the ordinary state without any asymmetric factors, and compounds 1-8 were obtained as stereoisomeric mixtures, including both the diastereoisomers and enantiomers from $( \pm)$-1a and $( \pm)-\mathbf{1 b}$ to $( \pm)-\mathbf{8 a}$ and $( \pm)-\mathbf{8 b}$ by coupling different phenols with the reduction product of methyl 3,4-dihydro-2H-pyran-5-carboxylate using previously reported conditions [33,34,37], as shown in Scheme 1. The core intermediate, methyl 3,4-dihydro-2 $H$-pyran-5-carboxylate, was easily prepared from commercially available 2,3-dihydropyran [40]. This ester was reduced with lithium aluminum hydride in anhydrous diethyl ether to yield the corresponding alcohol and immediately subjected to a $p$-toluene sulfonic acid-promoted electrophilic aromatic substitution with various phenols to afford targets $\mathbf{1}-\mathbf{8}$ in yields of $55 \%-90 \%$, depending on the phenol.

Scheme 1. Synthesis of compounds 1-8.

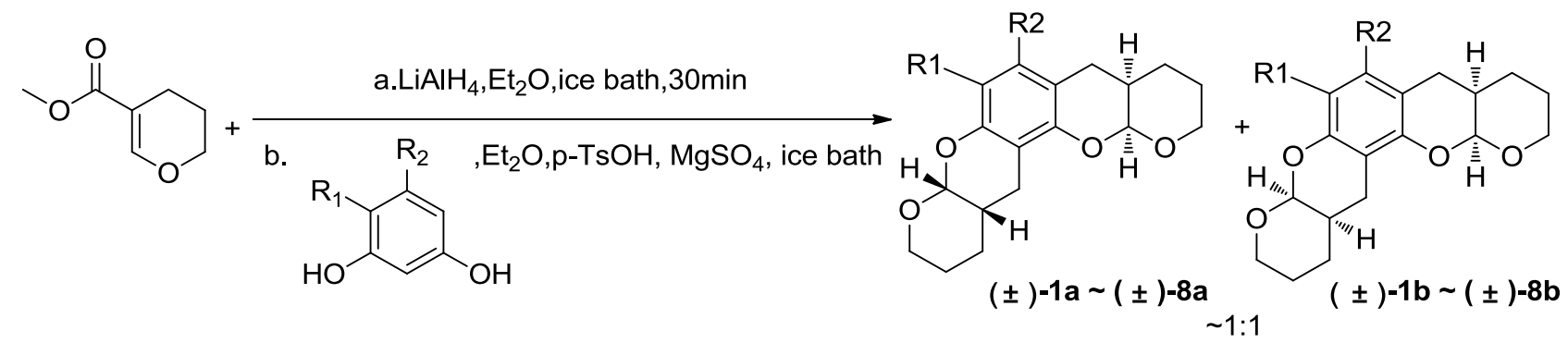
1: $\mathrm{R} 1=\mathrm{H}, \mathrm{R} 2=\mathrm{OH}$;
2: $\mathrm{R} 1=\mathrm{H}, \mathrm{R} 2=\mathrm{CH}_{3}$;
3: $\mathrm{R} 1=\mathrm{CH}_{3} \stackrel{\mathrm{C}}{\mathrm{C}}, \mathrm{R} 2=\mathrm{OH}$;
4: $\mathrm{R} 1=\mathrm{CH}_{3} \stackrel{\mathrm{O}}{\mathrm{C}}-, \mathrm{R} 2=\mathrm{H}$;
5: $\mathrm{R} 1=\mathrm{H}, \mathrm{R} 2=\mathrm{CH}_{3} \mathrm{OC}-$;
6: $\mathrm{R} 1=\mathrm{COOH}, \mathrm{R} 2=\mathrm{OH}$;
7: $\mathrm{R} 1=\mathrm{CH}_{3} \mathrm{OC}-, \mathrm{R} 2=\mathrm{OH}$;
8: $\mathrm{R} 1=\left(\mathrm{CH}_{3} \mathrm{CH}_{2}\right)_{2} \mathrm{NH}_{2}{ }^{+} \mathrm{O}$ OC-, $\mathrm{R} 2=\mathrm{OH}$; 
Scheme 2. Etherification of $\mathbf{1}$ using different alkylating agents to prepare 9-20.<smiles>Oc1cc2c(c3c1CC1CCCOC1O3)CC1CCCOC1O2</smiles>

1<smiles>[R7]Oc1cc2c(c3c1C[C@H]1CCCO[C@H]1O3)[C@H]1CCCO[C@@H]1O2</smiles>

( \pm )-9a $\sim( \pm)-20 \mathrm{a}$<smiles>[R2]c1cc2c(c3c1C[C@H]1CCCO[C@@H]1O3)[C@H]1CCCO[C@@H]1O2</smiles>

( \pm )-9b $\sim( \pm)-20 \mathrm{~b}$
9: $\mathrm{R}=\mathrm{CH}_{3}$;
10: $\mathrm{R}=\mathrm{CH}_{3} \mathrm{CH}_{2} \mathrm{O} \stackrel{\mathrm{O}}{\mathrm{C}} \mathrm{CH}_{2^{-}}$;
11: $\mathrm{R}=\left(\mathrm{CH}_{3}\right)_{2} \mathrm{CH}=\mathrm{CHCH}_{2}$;
12: $\mathrm{R}=\mathrm{CH}_{2}=\mathrm{CHCH}_{2}$;
13: $\mathrm{CH}_{3} \mathrm{CH}_{2} \mathrm{CH}_{2}$;
14: $\mathrm{R}=\left(\mathrm{CH}_{3}\right)_{2} \mathrm{CHCH}_{2} \mathrm{CH}_{2}-$;
15: $\mathrm{R}=\mathrm{CH}_{3} \mathrm{CH}_{2} \mathrm{OC}\left(\mathrm{CH}_{2}\right)_{2} \mathrm{CH}_{2}$
16: $\mathrm{R}=\mathrm{HO}\left(\mathrm{CH}_{2}\right)_{2} \mathrm{CH}_{2} ;$
17: $\mathrm{R}=\mathrm{CH}_{3}\left(\mathrm{CH}_{2}\right)_{5} \mathrm{CH}_{2^{-}}$;
18: $\mathrm{R}=\mathrm{H}_{3} \mathrm{C} \longrightarrow \mathrm{CH}_{2^{-}}$
; 19: $\mathrm{R}=\mathrm{F}_{3} \mathrm{C}-\mathrm{CH}_{2^{-}}$
;20: $\mathrm{R}=$

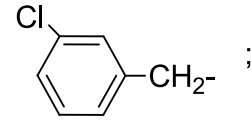

Scheme 3. Compounds 21-39 are the amide and carbonyl sulfide products of 6 .<smiles>[3H]CC1Cc2c3c(c(O)c(C(=O)O)c2OC2OCCCC2Cc2c(O)c(C(=O)OC)c4c(c21)CC1CCCOC1O4)CC1CCCOC1O3</smiles><smiles>[R]C(=O)c1c(O)c2c(c3c1O[C@@H]1OCCC[C@@H]1[C@H]3O)O[C@H]1CCCO[C@@H]1C2</smiles>

$( \pm)-21 a \sim( \pm)-39 a$<smiles>[R]C(=O)c1c(O)c2c(c3c1O[C@H]1OCCC[C@H]1O3)O[C@H]1CCCO[C@@H]1C2</smiles>

$( \pm)-21 b \sim( \pm)-39 b$

21: $\mathrm{R}=\mathrm{NH}_{2} ; \quad$ 22: $\mathrm{R}=\mathrm{CH}_{3} \mathrm{NH}-; \quad$ 23: $\mathrm{R}=\mathrm{CH}_{3}\left(\mathrm{CH}_{2}\right)_{3} \mathrm{NH}-; \quad$ 24: $\mathrm{R}=\mathrm{CH}_{3} \stackrel{\mathrm{O}}{\mathrm{C}} \mathrm{CH}\left(\mathrm{CH}_{3}\right) \mathrm{NH}-$;

25: $\mathrm{R}=\mathrm{CH}_{3}\left(\mathrm{CH}_{2}\right)_{3} \mathrm{~S}-$;

28: $R=$<smiles>CNC12CC3CC(CC(C3)C1)C2</smiles>

31: $\mathrm{R}=\mathrm{CH}_{3} \mathrm{OCC}$ (tert-Bu)NH- ; 32: $\mathrm{R}=\mathrm{CH}_{3} \mathrm{OCC} C H\left(\mathrm{CH}_{2} \mathrm{SH}\right) \mathrm{NH}-$;

34: $\mathrm{R}=\mathrm{Cl} \longrightarrow \mathrm{NH}-$;

35: $\mathrm{R}=\mathrm{HOCH}_{2} \mathrm{CH}_{2} \mathrm{NH}-$;

37: $\mathrm{R}=\left(\mathrm{CH}_{3}\right)_{2} \mathrm{NCH}_{2} \mathrm{CH}_{2} \mathrm{NH}-;$
26: $\mathrm{R}=\left\langle\mathrm{S}_{\mathrm{S}} \| \mathrm{CH}_{2} \mathrm{CH}_{2} \mathrm{NH}-\right.$ $\mathrm{H}_{2} \mathrm{NOC}$

29: $\mathrm{R}=$<smiles>Cc1cccc(N[14CH2][13CH2][R]Oc2ccc(CCN[NH3+])cc2)c1</smiles>

33: $\mathrm{R}=\mathrm{F}-\mathrm{NH}-$

36: $\mathrm{R}=\square-\mathrm{CH}_{2} \mathrm{~N}(\mathrm{i}-\mathrm{Pr})$

39: $\mathrm{R}=\mathrm{HSCH}_{2} \mathrm{CH}_{2} \mathrm{NH}$. 
These compounds were isolated as bis-adduct analogues to Xyl-B and were easily characterized as angular via NMR spectroscopy, which is consistent with the authentic natural product and previous synthetic work, because linear compounds can convert into the more stable angular molecules $[21,33]$. The two oxygen-containing pyran rings, $\mathrm{B}$ and $\mathrm{C}$, can be connected in a cis or trans fashion. Previous studies indicate that rings $\mathrm{B}$ and $\mathrm{C}$ were $\mathrm{cis}$ in the natural and synthetic compounds for all condensations, leading to xyloketal derivatives [28-36]. Therefore, two sets of xyloketal derivative diastereoisomers can be formed.

Separating the diastereoisomers via chromatography was very difficult, because of their similarity. In the HPLC analysis, most of the final products showed one or two close peaks under the experimental conditions. The LC-MS results gave the same molecular weight for these two peaks, which suggests that the compounds were diastereomeric mixtures (see the Supplementary Information). However, we found that the diastereoisomers of compound $\mathbf{6}$ could be separated through repeated chromatography and crystallization. Thus, product 6 was analyzed as an example. Compound 6 was purified via flash chromatography followed by crystallization to afford two pure ingredients, $( \pm)$-6a and $( \pm)$-6b (Chart 3). A single ( \pm )-6a crystal was used for X-ray crystal analysis (Chart 3A). This analysis confirmed that $( \pm)$-6a was isolated as a mixture of an enantiomers pair. The crystal structure indicated that the rings were angularly arranged similar to the natural product, xyloketal B; the orientation of rings $\mathrm{C}$ and $\mathrm{C}^{\prime}$ was the anti-type, and $\mathrm{H}-2$ and $\mathrm{H}-7$, as well as $\mathrm{H}-2$ 'and H-7' were cis (the NMR and X-ray data for compound 6 is provided in the Supplementary Information.). Most signals in the 1D and 2D NMR spectra for ( \pm -6 $6 \mathbf{b}$ and ( \pm )-6a were similar. In the ${ }^{1} \mathrm{H}$ NMR spectrum for $( \pm)-6 \mathbf{b}$, the coupling constants between H-2 and H-7 and between H-2'and H-7' were 2.4 and $2.8 \mathrm{~Hz}$, respectively, which indicates a syn relationship, as in ( \pm )-6a. However, some changes were observed in the ${ }^{13} \mathrm{C}$ NMR spectra, especially in the C-4 and C-8 shifts in ( \pm )-6a and $( \pm)-6 \mathbf{b}$, which differed by $\delta_{\mathrm{C}} 0.41$ and 0.37 , respectively. Finally, $( \pm)-6 \mathbf{b}$ was established as the diastereoisomer of $( \pm)-6 a$ via NMR analysis. The methenyl hydrogen atoms $\left(\mathrm{H}-2,2^{\prime}\right)$ in the ${ }^{1} \mathrm{H}$ NMR spectra of the mixtures were doublets of doublets with chemical shifts of 5.53 and 5.37 for $( \pm)-6 \mathbf{a}$ and 5.52 and 5.35 for $( \pm)-6 \mathbf{b}$. The integral of the H-2 and $2^{\prime}$ peaks in the mixture of $( \pm)-6 \mathbf{a}$ and $( \pm)-6 \mathbf{b}$ showed that the diastereoisomeric ratio was $\sim 1: 1$. Moreover, the integral ratio of the carbon atoms $\left(\mathrm{C}-7,7^{\prime}\right)$ in the mixtures of $( \pm)-6 \mathbf{a}(\delta=30.89,30.66)$ and $( \pm)-6 \mathbf{b}(\delta=30.81,30.75)$ was $\sim 1: 1$, which supported the diastereoisomeric ratio $(1: 1)$ found for $\mathbf{6}$. Although we separated small amounts of diastereoisomers of compound $\mathbf{6}$, we performed all further modifications and biological evaluations using the mixture of $\mathbf{6}$ and its diastereoisomers; thus, the activity of $\mathbf{6}$ could be compared with those of the other compounds.

The NMR spectra for 1-8 show diastereoisomeric features similar to those of $\mathbf{6}$. For example, both the ${ }^{1} \mathrm{H}$ and ${ }^{13} \mathrm{C}$ NMR spectra of $\mathbf{1}$ show evidence of the diastereoisomers, $( \pm)-\mathbf{1 a}$ and $( \pm)-\mathbf{1 b}$, which have overlapping peaks. The aromatic carbon atom (C-12) resonates as a single peak, and the methenyl (C-2, C-2') and methylene groups (C-4, C-4') both present as four closely packed peaks. Moreover, the methenyl groups $\left(\mathrm{C}-7,7^{\prime}\right)$ also appear as four peaks $(\delta=31.24,31.20,31.11$ and 31.08$)$. These peaks all indicate that compound $\mathbf{1}$ consists of two sets of diastereoisomers. Comparing the carbon atoms $\left(\mathrm{C}-7,7^{\prime}\right)$ in $( \pm)-\mathbf{6 a}$ and $( \pm)-\mathbf{6 b}$ to those in $\mathbf{1}$ indicates that the peaks at $\delta=31.24$ and 31.08 and those at $\delta=31.20$ and 31.11 belong to diastereoisomers $( \pm)-\mathbf{1 a}$ and $( \pm)-\mathbf{1 b}$, respectively. The integral of the 
carbon atoms, C-7 and C-7', indicates an approximately 1:1 ratio of diastereoisomers $( \pm)-\mathbf{1 a}$ and $( \pm)-\mathbf{1 b}$. The structures of compounds $\mathbf{2}-\mathbf{8}$ were determined using the same methods used for $\mathbf{1}$.

Chart 3. The structures for ( \pm )-6a (A) and ( \pm )-6b (B); X-ray structure for one isomer of $( \pm)$-6a from the front $(\mathbf{C})$ and side $(\mathbf{D})$ views.

(A)

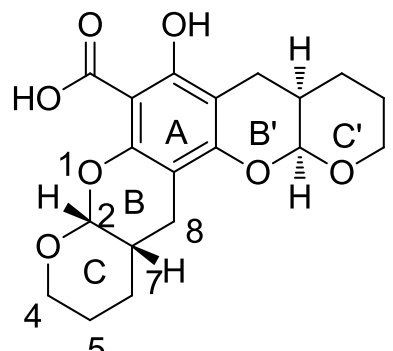

( \pm )-6a (X-ray)

(C)

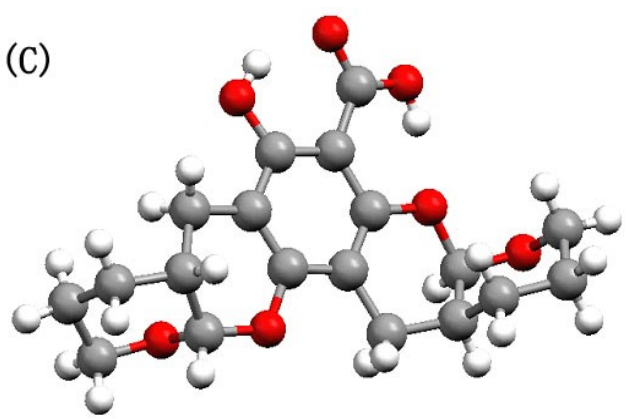

(B)<smiles>O=C(O)c1c(O)c2c(OCCCO)c3c1O[C@H]1C[C@H]3OCCC[C@@H]1O2</smiles>

$( \pm)-6 b$

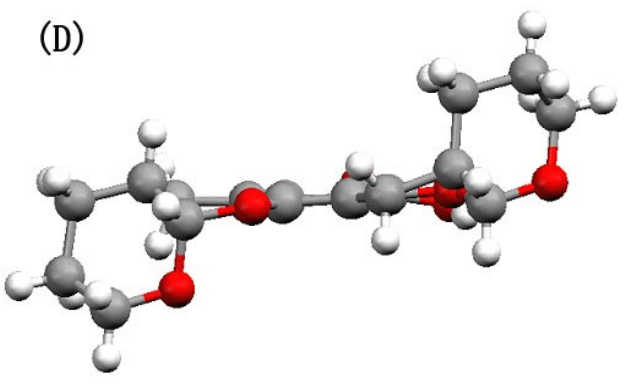

Compounds 9-20 (Scheme 2) were produced in high yield via etherification of the hydroxyl groups on 1 using dimethyl sulfate or various alkyl bromides in the presence of potassium carbonate [37]. The etherification reactions of $\mathbf{1}$ did not involve the chiral carbons, and we reasoned that the stereochemistry of these compounds remained the same as those for the precursor, $\mathbf{1}$. Therefore, two sets of diastereoisomers were likely formed for each derivative in a $\sim 1: 1$ ratio. This assumption was supported by the NMR data.

The synthetic route to 21-39 is shown in Scheme 3. The target compounds were also obtained as mixtures of stereoisomers from $( \pm)$-21a and $( \pm)$-21b to $( \pm)$-39a and $( \pm)$-39b, which were synthesized by coupling 6 with the corresponding amine or thiol under moderate reaction conditions in the presence of (benzotriazol-1-yloxy)tris(dimethylamino)phosphonium hexafluorophosphate (BOP) and $\mathrm{N}, \mathrm{N}$-diisopropylethylamine (DIEA) or by the amination of 7 [37]. Compound $\mathbf{8}$ is the diethylamine salt of 6 and shows improved water solubility. The NMR spectra for 21-39 indicate diastereoisomeric features similar to those of $\mathbf{6}$. The coupling reactions resulted in the desired compounds without affecting the chiral carbons; thus, the amide and carbonyl sulfide products (21-39) should retain the stereochemistry of 6 .

\subsection{Xyloketal Derivatives Attenuate the PMA-Induced Neurotoxicity in a Zebrafish Respiratory}

\section{Burst Assay}

The antioxidant activity of the xyloketal derivatives were examined via a zebrafish respiratory burst assay. In these zebrafish respiratory burst assays, phorbol myristate acetate (PMA) was used to activate NADPH oxidase and to induce the generation of excessive quantities of ROS; therefore, a 
nonfluorescent dye, such as $2^{\prime}, 7^{\prime}$-dihydrodichlorofluorescein diacetate ( $\left.\mathrm{H}_{2} \mathrm{DCFDA}\right)$, could be used to detect the ROS formation based on its oxidization to fluorescent dichlorofluorescein (DCF).

Separating the diastereoisomers was very difficult; therefore, all 39 xyloketal derivatives were used directly in the biological screenings without separating the diastereoisomers. These compounds were obtained through the same synthetic methods and possessed the same structural framework and ring fusion stereochemistry; the only differences were the benzene ring substituents. Although the test compounds are enantiomeric and diastereomeric mixtures, their activity and a preliminary SAR analysis was obtained.

Figure 1. Effect of compounds on phorbol myristate acetate (PMA)-induced reactive oxygen species (ROS) in a respiratory burst assay. Zebrafish were pretreated $72 \mathrm{~h}$ post-fertilization (hpf) with one of the compounds or dimethyl sulfoxide (DMSO) for $30 \mathrm{~min}$ and then incubated with PMA and $2^{\prime}, 7^{\prime}$-dihydrodichlorofluorescein diacetate $\left(\mathrm{H}_{2} \mathrm{DCFDA}\right.$ ) for $150 \mathrm{~min}$ at $28{ }^{\circ} \mathrm{C}$. Relative fluorescence units (RFUs) were measured using a fluorescent instrument (ex. of $485 \mathrm{~nm}$ and em. of $530 \mathrm{~nm}$ ). The RFUs of the PMA group were set to $100 \%$, and the other groups are shown relative to this group. Data were processed via a one-way ANOVA followed by a post hoc test (Games Howell method) (* $p<0.01$ vs. PMA, $n=6$ wells for each group). Three independent experiments were performed.

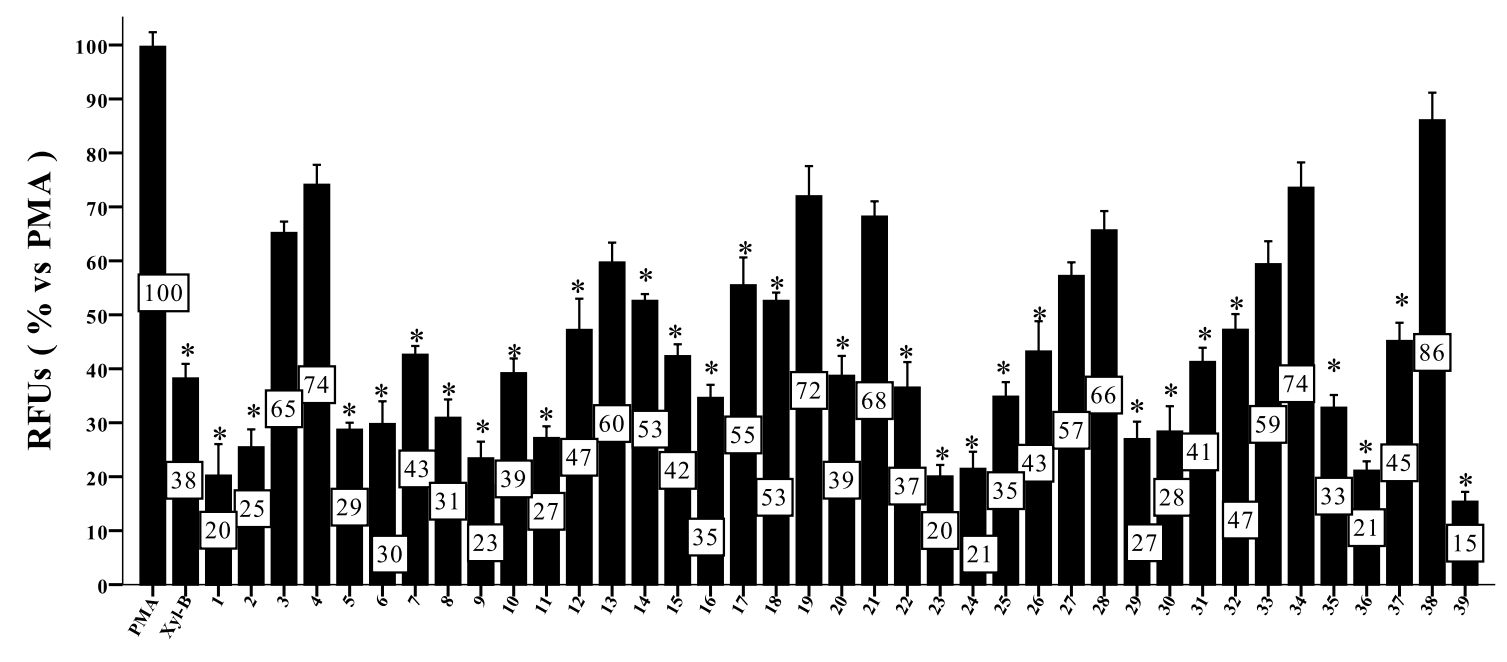

groups

The results (Figure 1) showed that most of the compounds exhibited strong antioxidative activity ( $p<0.01$ vs. PMA). Compounds 1, 9, 23, 24, 36 and 39 reduced the ROS level significantly to $<25 \%$ at $50 \mu \mathrm{M}$ and are more active antioxidants than Xyl-B, which reduced the ROS level to $<38 \%$ vs. PMA. Because none of the ether derivatives, except 9, 11 and 16, showed improved antioxidant activity relative to $\mathbf{1}$, the hydroxyl group in the 11 position of $\mathbf{1}$ must be important, but not necessary, for this activity. Additionally, compounds $\mathbf{2}$ and $\mathbf{5}$ showed good activity despite the replacement of the hydroxyl group in the 11 position with a methyl or methyl carboxyl group. Amide derivatives containing the hydrophilic groups of $\mathbf{1}$, such as $\mathbf{2 6}, \mathbf{2 9}, \mathbf{3 0}, \mathbf{3 5}, \mathbf{3 7}$ and 39, exhibited higher antioxidative activities than those with hydrophobic and aromatic groups, such as $27,28,33,34,38$. However, 36 is a special case and showed very high antioxidative activity with both hydrophobic 
propyl and benzyl groups. Compounds with alkyl group substituents that are too large, such as $\mathbf{3 8}$, showed unfavorable antioxidative activity. Moreover, amides containing amino acids, such as 24, 31, and 32, all exhibited marked activities. Specifically, compound 39, with the mercapto group, showed the highest activity of all compounds tested.

\subsection{Xyloketal Derivatives Attenuate the Juglone-Induced Reduction of Worm Viability}

As previously reported, juglone oxidants significantly reduce worm viability. A longevity-extending assay using a juglone oxidant to generate ROS and damage the worms was performed with all of the derivatives. The survival time of worms could be extended by pretreatment with the xyloketal compounds. The survival curve showed that the survival rates directly reflected the protective effects of the different compounds (Figure 2). The calculated mean survival times for all test compounds are given in Figure 3.

Figure 2. Survival analysis of the representative compounds $\mathbf{1}$ and Xyl-B in juglone-treated C. elegans using the Kaplan-Meier method. The worms were synchronized using sodium hypochlorite and sodium hydroxide. Forty-eight $\mathrm{h}$ later, the synchronized worms were further treated with $100 \mu \mathrm{M}$ of the test compound in their food for an additional $48 \mathrm{~h}$. All worms were then treated with $200 \mathrm{ng} / \mathrm{mL}$ of juglone, and the number of dead worms was immediately counted. DMSO was used as a control. The survival curve shows the time-dependent cumulative proportional survival rate. Three independent experiments were performed for each group, and each group contained 50 worms.

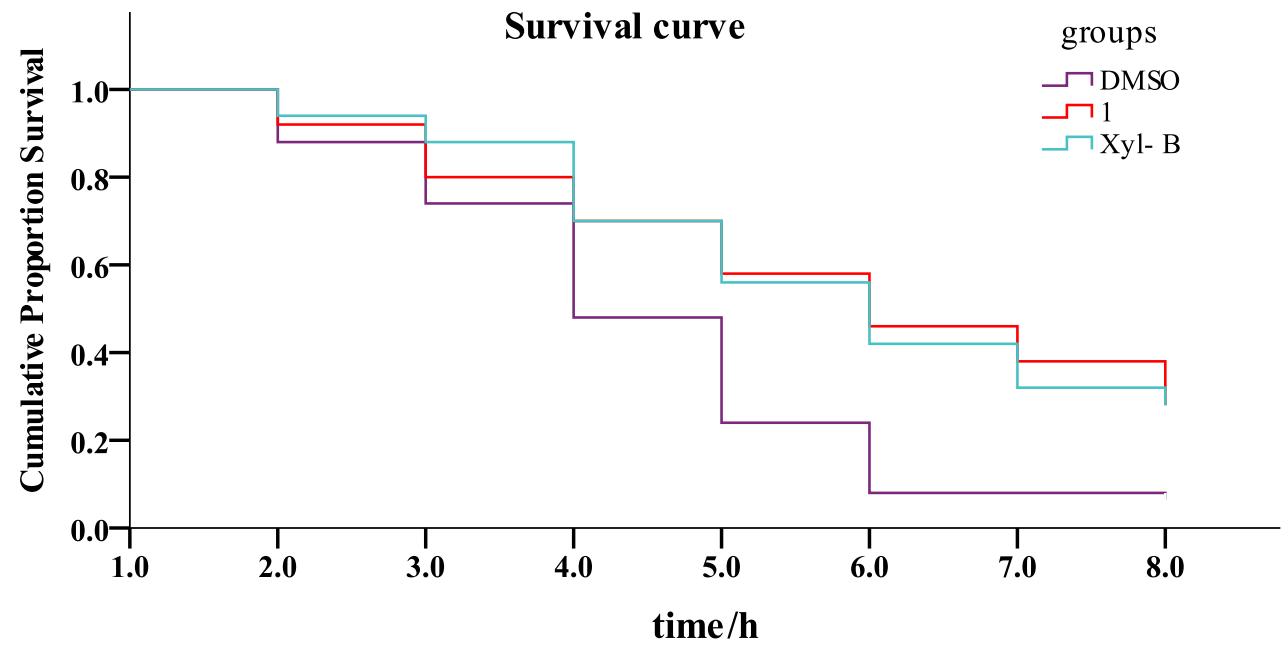

There were 14 molecules with strong longevity-promoting activity ( $p<0.05$, Figure 3 ). Of these compounds, Xyl-B, 1, 8, 15, 16 and 36 significantly extended the survival rates ( $p<0.005 v s$. DMSO). Notably, compounds $\mathbf{8}$ and $\mathbf{1 6}$ exhibited the strongest protective effects against juglone toxicity and extended the mean survival time of the worms by $132 \%$ and $134 \%$, respectively. Similar to the respiratory burst assay, most of the amides containing hydrophilic groups exhibited higher antioxidative activity than those with hydrophobic or aromatic groups; however, $\mathbf{3 6}$ was a special case that showed very high antioxidative activity with both hydrophobic propyl and benzyl groups. 
Figure 3. The mean survival times for all of the test compounds analyzed via the Kaplan-Meier method. The worms were synchronized using sodium hypochlorite and sodium hydroxide. Forty-eight $\mathrm{h}$ later, the synchronized worms were further treated with $100 \mu \mathrm{M}$ of the test compound in their food for an additional $48 \mathrm{~h}$. All worms were then treated with $200 \mathrm{ng} / \mathrm{mL}$ of juglone, and the number of dead worms was immediately counted. The mean survival time of the DMSO control was normalized to $100 \%$, and the other times are reported relative to this control. ( ${ }^{*} p<0.05$ and $* * p<0.005$ vs. DMSO group, $n=50$ for each group). Three independent experiments were performed.

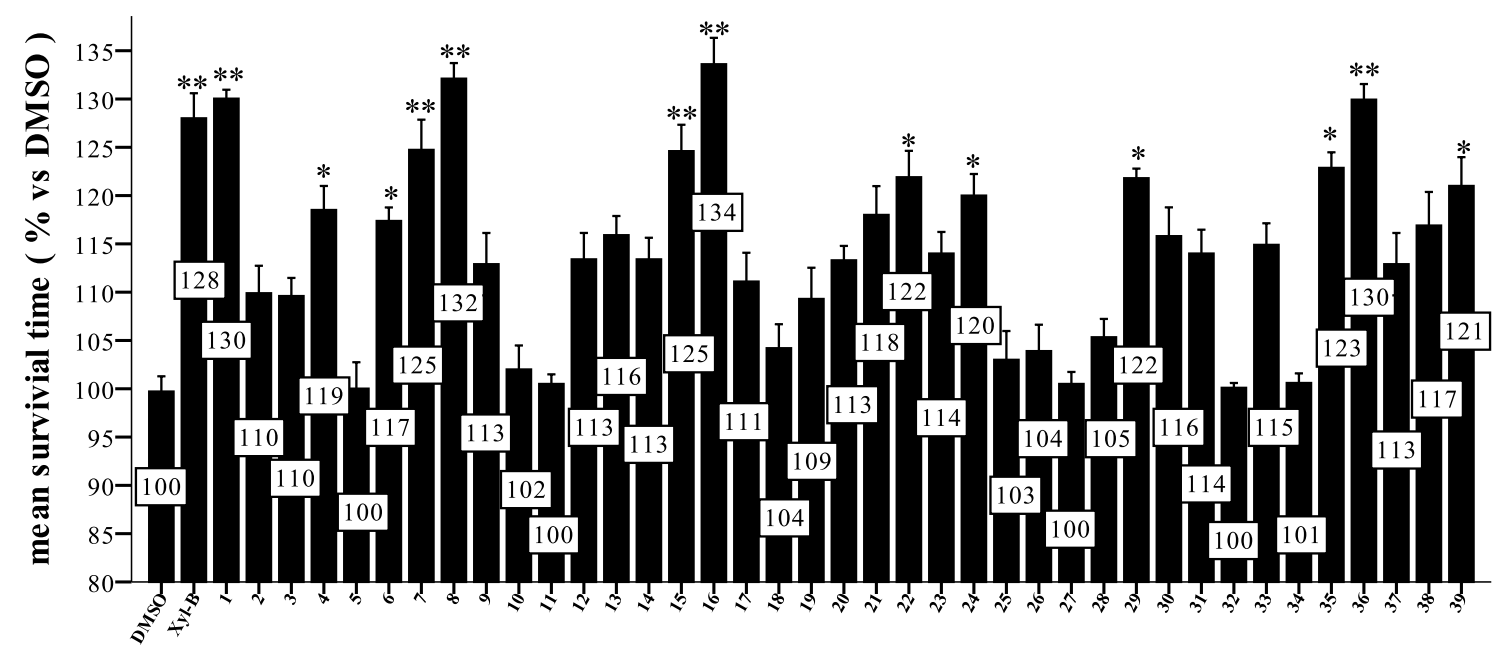

groups

The two in vivo antioxidative models used above indicated that xyloketal derivatives with benzopyrano pyran skeletons instead of benzopyrano furan skeletons showed increased antioxidative and neuroprotective activities in vivo.

\subsection{Neuroprotective Action of Selected Compounds in the MPP+-Induced C. elegans PD Model}

Because ROS play an important role in neurodegenerative diseases, including PD, the 15 compounds with the highest antioxidative activities were selected for further evaluation of their neuroprotective activities using an MPP+-induced C. elegans PD model. In C. elegans, MPP+ induces dramatic DA degeneration that leads to death (Figure 4). The survival rates indicate the protective results of the tested compounds (Figure 5).

The majority of test compounds provided good protection against MPP+-induced toxicity, which indicates that their neuroprotective activities were likely related to their antioxidative activities. Compounds 1, 6, 8 and 16 showed the highest activities of the test compounds ( $p<0.005 v s$ MPP + ). Compound $\mathbf{8}$, the diethylamine salt of $\mathbf{6}$, exhibited the strongest antioxidative activity of the examined compounds and increased the MPP+-treated worm survival rate by a remarkable $29 \%$ from $52 \%$ to $81 \%$. 
Figure 4. The effects of the tested compounds on 1-methyl-4-phenylpyridinium (MPP+)-induced dopaminergic (DA) neurodegeneration using the MPP+-induced C. elegans Parkinson's disease (PD) model. The representative fluorescence images show dopaminergic neurons in the BZ555 worm strain. All images were captured using a fluorescent microscope with a $2 \mathrm{~ms}$ exposure time. (A) Normal control worms exhibited a green fluorescent protein (GFP) signal in cells for three pairs of anterior dopaminergic neurons. The arrows indicate the three DA neuron pairs, which include two CEP neuron pairs and one ADE neuron pair. (B) In contrast, worms treated with $1 \mathrm{mM} \mathrm{MPP}+$ for $48 \mathrm{~h}$ showed DA neurodegeneration, observed by the loss of GFP signal in the cells, dendrites (CEPs) and axons (ADEs) of DA neurons. (C) Treatment with compound 1 significantly attenuated MPP+-induced degeneration in the cell bodies and axons (ADEs), but not in the dendrites (CEPs).
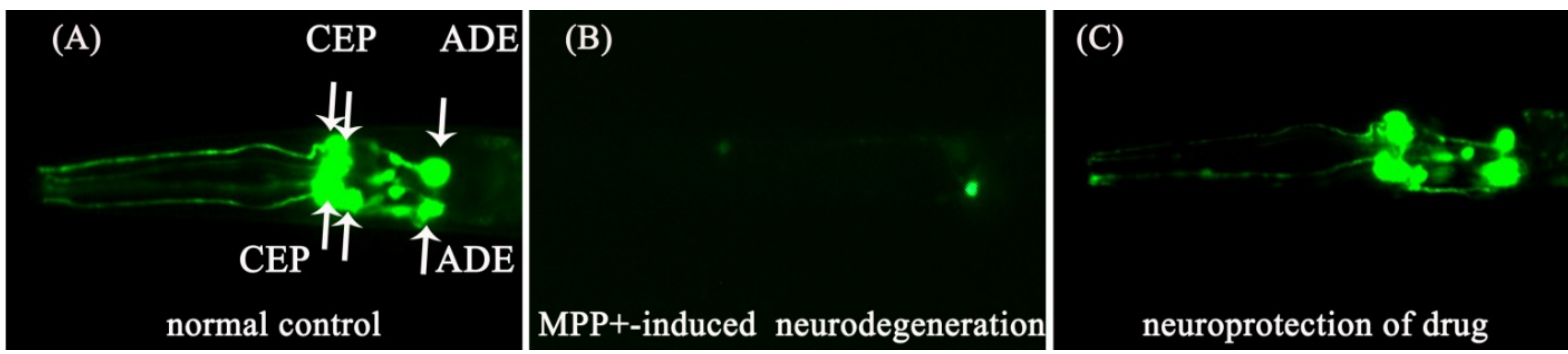

Figure 5. The survival rates for different groups in the MPP+-induced C. elegans PD model. Synchronized worms were allowed to hatch to the L1 stage. The worms were treated with $100 \mu \mathrm{M}$ of the test compound or DMSO, followed by treatment with $1 \mathrm{mM}$ $\mathrm{MPP}+$ before incubating at $20{ }^{\circ} \mathrm{C}$. Approximately $48 \mathrm{~h}$ after MPP + exposure, worm viability was evaluated using a microscope. The survival rate of the DMSO group was normalized to $100 \%$ as the blank control, and the MPP+ group treated with $1 \mathrm{mM}$ MPP+ was used as the vehicle control and was approximately 50\%. The rates of the other groups are reported relative to the black control. Comparison of the means was performed using a one-way ANOVA followed by a post hoc test (LSD method) ${ }^{*} p<0.05$ and ** $p<0.005$ vs. MPP,$+ n=6$ wells for each group). Three independent experiments were performed for each group.

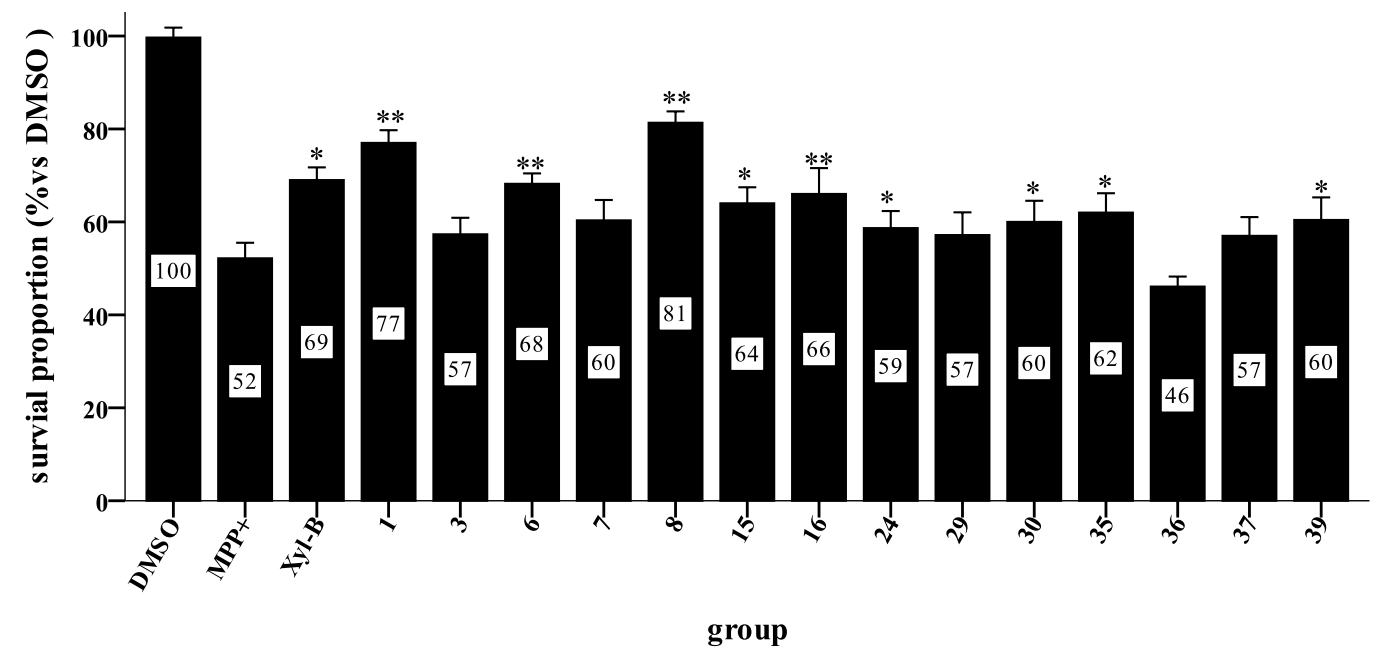




\subsection{Neuroprotective Activity of $\mathbf{1}$ and $\mathbf{8}$ in the MPP+-Induced Mouse PD Model}

We further investigated the neuroprotective effects of compounds $\mathbf{1}$ and $\mathbf{8}$, the two most promising compounds, using the MPP+-induced C57BL/6 mouse PD model. The model group was injected with $30 \mathrm{mg} / \mathrm{kg}$ of MPTP daily, and $40 \mathrm{mg} / \mathrm{kg}$ or $100 \mathrm{mg} / \mathrm{kg}$ of 1 and 8 were given to the administration groups intraperitoneally following the MPTP injection. An examination of the dopaminergic neurons in the brain tissue slices from the substantia nigra ( $\mathrm{SN}$ ) was measured using an immunofluorescence technique, and the results are shown in Figure 6.

Figure 6. The effects of compounds $\mathbf{1}$ and $\mathbf{8}$ on the dopaminergic substantia nigra (SN) neurons using the MPP+-induced mouse PD model. Mice groups were injected with the test compounds ( $40 \mathrm{mg} / \mathrm{kg}$ and $100 \mathrm{mg} / \mathrm{kg}$ ) or saline for five days following treatment with MPTP $(30 \mathrm{mg} / \mathrm{kg})$ or injected with saline for six days. The brain tissues were collected immediately after being transcardially perfused. Immunofluorescent technology was used to observe the DA neurons. (A) The upper images were captured with a fluorescent microscope using $100 \times$ magnification, and the other images used $200 \times$ magnification. (B) The number of DA neurons for the different groups. The control group was normalized to $100 \%$, and the other groups are presented as a percentage of the control. Comparison of the means was performed via a one-way ANOVA followed by a post hoc test (LSD method). (** $p<0.001 v s$. MPP,$+ n=6)$.

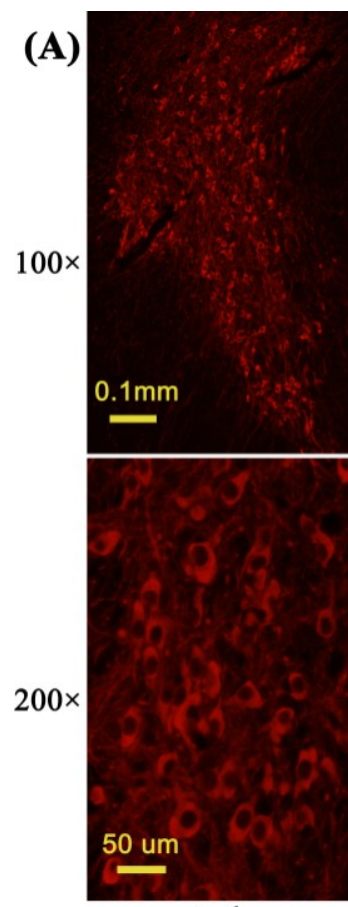

control

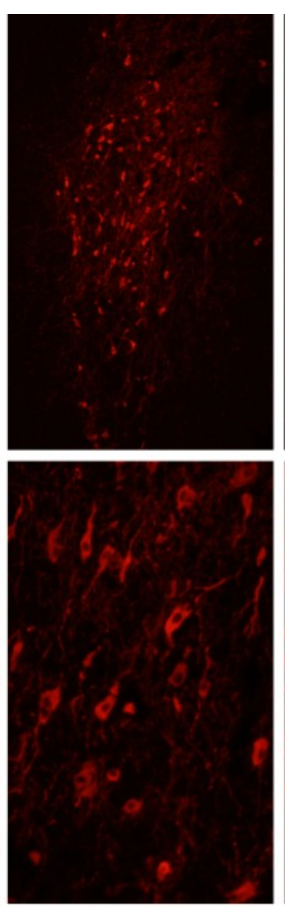

MPP+
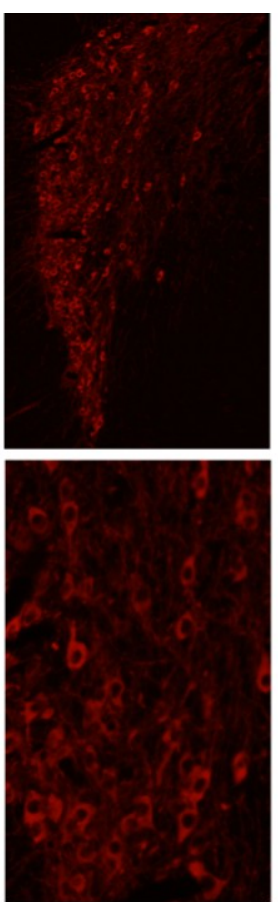

$1(40 \mathrm{mg} / \mathrm{kg})$
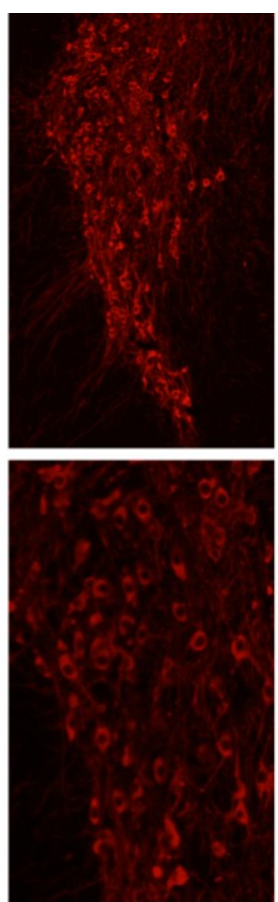

$1(100 \mathrm{mg} / \mathrm{kg})$

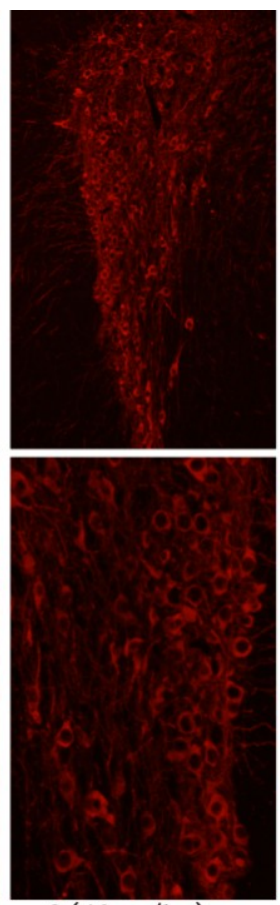

$8(40 \mathrm{mg} / \mathrm{kg})$
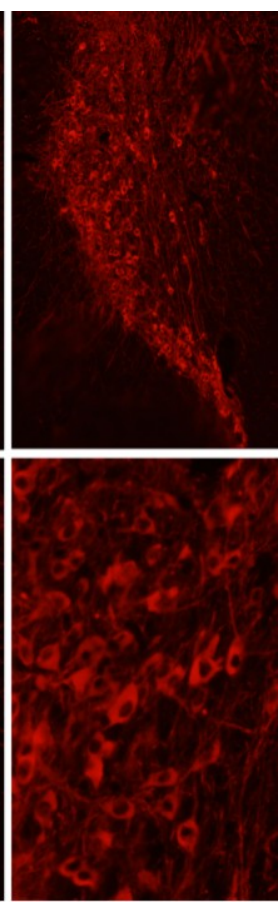

$8(100 \mathrm{mg} / \mathrm{kg})$ 
Figure 6. Cont.

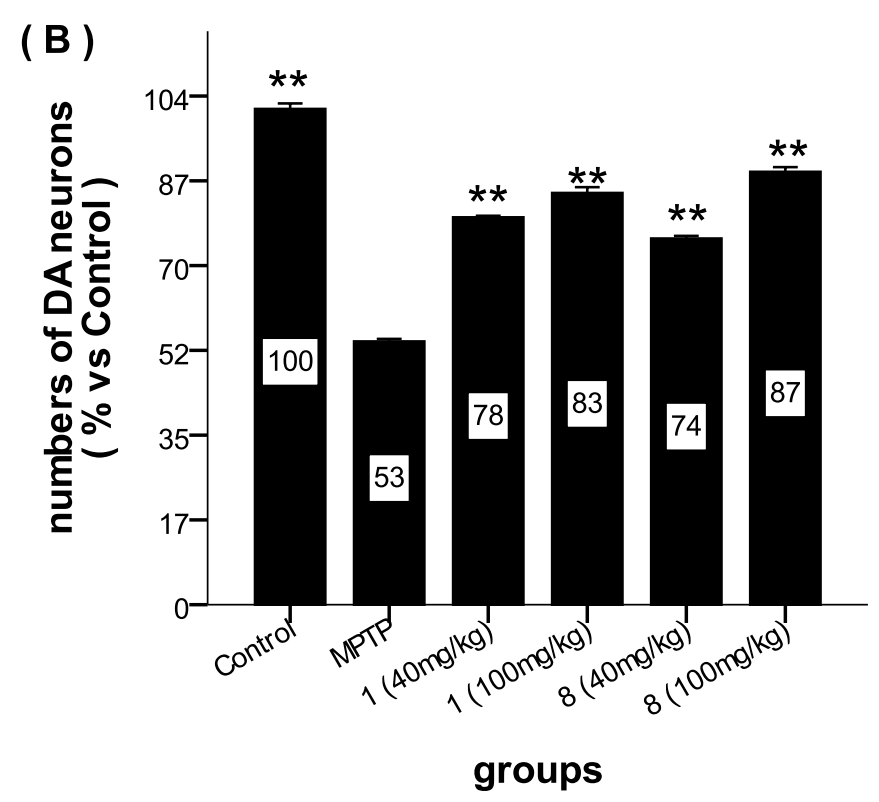

The staining indicated that the morphology and number of dopaminergic neurons were altered in the MPTP-treated mice, and both $\mathbf{1}$ and $\mathbf{8}$ showed remarkable neuroprotective activity (Figure 6A). The number of dopaminergic neurons in the SN tissues was measured using the ImageJ software, and the results are shown in Figure 6B. The control group showed a normal DA neuron number, and the number of DA neurons in this group was normalized to $100 \%$. The MPP+-treated group showed obvious neurodegeneration, with a $53 \%$ reduction in the number of dopaminergic neurons in the SN tissue after MPTP injection. Compounds $\mathbf{1}$ and $\mathbf{8}$ showed significant improvement in the number of DA neurons, $78 \%$ and $74 \%$, respectively, with a $40 \mathrm{mg} / \mathrm{kg}$ dose ( $p<0.001 \mathrm{vs}$. MPP + group) and $83 \%$ and $87 \%$, respectively, with a $100 \mathrm{mg} / \mathrm{kg}$ dose ( $p<0.001 v s$. MPP+ group). Immunofluorescence analysis of the dopaminergic neurons in the brain tissue slices after treating the $C 57 B L / 6$ mice with different drug concentrations showed that $\mathbf{1}$ and $\mathbf{8}$ attenuated MPTP toxicity in a dose-dependent manner.

A biological examination of the results revealed that all of the test compounds, except 19 and 28 , showed potent antioxidative activity in both antioxidative models, and compounds containing a benzopyrano pyran skeleton or an amide with hydrophilic substituents demonstrated improved antioxidative activity. For the $C$. elegans PD model, all selected compounds, except 36, displayed strong neuroprotective activity. Compounds Xyl-B, 1, 6, 8 and 16 showed potent activity in both the antioxidative and neuroprotective tests. The mouse PD model further demonstrated the neuroprotective activity of this series of compounds. These findings demonstrate that the newly synthesized xyloketal derivatives are promising candidates for the treatment of PD.

\section{Experimental Section}

\subsection{Chemistry}

All commercially available reagents and solvents were used directly without further purification, unless otherwise stated. ${ }^{1} \mathrm{H}$ and ${ }^{13} \mathrm{C}$ NMR data were recorded on a $300 \mathrm{MB}$ NMR spectrometer operating at $300 \mathrm{MHz}$ and $75 \mathrm{MHz}$ for ${ }^{1} \mathrm{H}$ and ${ }^{13} \mathrm{C}$, respectively, and a $400 \mathrm{MB}$ NMR operating at 
$400 \mathrm{MHz}$ and $100 \mathrm{MHz}$ for ${ }^{1} \mathrm{H}$ and ${ }^{13} \mathrm{C}$, respectively. The deuterated solvents contained tetramethylsilane (TMS) as an internal standard, and all chemical shifts are in ppm $(\delta)$. Mass spectra were obtained using a DSQ (low resolution mass spectrometer) and MAT95XP (high resolution mass spectrometer).The purities of all test compounds were at least $95 \%$, as determined by an HPLC equipped with a UV detector at $254 \mathrm{~nm}$ with a C18 column $(5 \mu \mathrm{m}, 4.6 \times 250 \mathrm{~mm})$ at $25^{\circ} \mathrm{C}$.

\subsection{Synthesis of Intermediates}

\subsubsection{5-(Trichloroacetyl)-3,4-dihydro-2H-pyran}

To a solution of 2,3-dihydropyran (30 g, $0.36 \mathrm{~mol})$ and pyridine $(30 \mathrm{~g}, 0.38 \mathrm{~mol})$ in $200 \mathrm{~mL}$ chloroform at $-40{ }^{\circ} \mathrm{C}$ was added trichloroacetyl chloride $(77 \mathrm{~g}, 0.43 \mathrm{~mol})$ dropwise. The resultant solution was then stirred for $2 \mathrm{~h}$ at $-40{ }^{\circ} \mathrm{C}$ and 1 hour at room temperature before pouring into a mixture of ice and water. The obtained mixture was washed with $1 \mathrm{M} \mathrm{HCl}(2 \times 100 \mathrm{~mL})$, water $(100 \mathrm{~mL})$, saturated $\mathrm{NaHCO}_{3}(100 \mathrm{~mL})$ and saturated brine $(100 \mathrm{~mL})$. The separated chloroform layer was dried over anhydrous magnesium sulfate and concentrated in vacuo to afford the crude product ( $71 \mathrm{~g}, 0.31 \mathrm{~mol}, 86 \%$ yield) as a pale yellow oil. Because it is unstable at room temperature, the crude oil was immediately used in subsequent experiments without further purification. ${ }^{1} \mathrm{H}$ NMR $(300 \mathrm{MH} \mathrm{z}$, $\left.\mathrm{CDCl}_{3}\right) \delta 8.17(\mathrm{~s}, 1 \mathrm{H}), 4.14(\mathrm{t}, J=5.3 \mathrm{~Hz}, 2 \mathrm{H}), 2.40(\mathrm{t}, J=6.4 \mathrm{~Hz}, 2 \mathrm{H}), 2.00-1.89(\mathrm{~m}, 2 \mathrm{H}) .{ }^{13} \mathrm{C} \mathrm{NMR}$ $\left(75 \mathrm{MHz}, \mathrm{CDCl}_{3}\right) \delta 180.26,161.59,106.56,95.78,67.26,21.01,20.02$.

\subsubsection{3,4-Dihydro-2H-pyran-5-carboxylic Acid}

To a solution of crude 5-(trichloroacetyl)-3,4-dihydro- $2 H$-pyran $(71 \mathrm{~g}, 0.31 \mathrm{~mol})$ in $150 \mathrm{~mL}$ of THF was added $150 \mathrm{~mL}$ of an aqueous $\mathrm{LiOH} \cdot \mathrm{H}_{2} \mathrm{O}(17 \mathrm{~g}, 0.4 \mathrm{~mol})$ solution. The resultant mixture was stirred for $2 \mathrm{~h}$ in a water bath and diluted with $100 \mathrm{~mL}$ water. The THF was then removed under reduced pressure on a rotary evaporator, and the remaining solution was washed with chloroform $(3 \times 100 \mathrm{~mL})$ and adjusted to a $\mathrm{pH}$ value of 6 using concentrated $\mathrm{HCl}$. The resultant mixture was extracted with chloroform $(3 \times 100 \mathrm{~mL})$. The combined organic layer was washed with saturated brine $(100 \mathrm{~mL})$, dried over anhydrous magnesium sulfate and concentrated in vacuo to afford the crude product (37 g, $0.29 \mathrm{~mol}, 93 \%$ yield) as a light yellow solid. Purification by flash chromatography yielded a white solid. ${ }^{1} \mathrm{H}$ NMR $\left(300 \mathrm{MHz}, \mathrm{CDCl}_{3}\right) \delta 7.69(\mathrm{~s}, 1 \mathrm{H}), 4.07(\mathrm{t}, J=5.1 \mathrm{~Hz}, 2 \mathrm{H})$, $2.27(\mathrm{t}, J=6.3 \mathrm{~Hz}, 2 \mathrm{H}), 2.03-1.74(\mathrm{~m}, 2 \mathrm{H}) .{ }^{13} \mathrm{C} \mathrm{NMR}\left(75 \mathrm{MHz}, \mathrm{CDCl}_{3}\right) \delta 173.55,157.27,105.14$, $66.86,21.06,18.90$.

\subsubsection{Methyl 3,4-Dihydro-2H-pyran-5-carboxylate}

To a solution of 3,4-dihydro-2H-pyran-5-carboxylic acid (37 g, $0.29 \mathrm{~mol})$ and dimethyl sulfate $(37 \mathrm{~g}, 0.29 \mathrm{~mol})$ in acetone $(300 \mathrm{~mL})$ was added potassium carbonate $(52 \mathrm{~g}, 0.38 \mathrm{~mol})$ at room temperature. The resultant solution was stirred overnight, and the acetone was removed under reduced pressure on a rotary evaporator. The obtained mixture was dissolved in $150 \mathrm{~mL}$ of water and extracted with ethyl acetate $(3 \times 100 \mathrm{~mL})$. The combined organic layer was washed with water $(100 \mathrm{~mL})$, saturated $\mathrm{NaHCO}_{3}(100 \mathrm{~mL})$ and saturated brine $(100 \mathrm{~mL})$ before drying over anhydrous magnesium sulfate and concentrating in vacuo. Flash chromatography purification using ethyl acetate:petroleum 
ether (1:20) as the eluant afforded the title compound (35 g, $0.25 \mathrm{~mol}, 84 \%$ yield) as a colorless liquid. ${ }^{1} \mathrm{H}$ NMR $\left(300 \mathrm{MHz}, \mathrm{CDCl}_{3}\right) \delta 7.46(\mathrm{t}, J=1.1 \mathrm{~Hz}, 1 \mathrm{H}), 3.94(\mathrm{t}, J=5.2 \mathrm{~Hz}, 2 \mathrm{H}), 3.60(\mathrm{~s}, 3 \mathrm{H})$, $2.16(\mathrm{td}, J=6.4,1.2 \mathrm{~Hz}, 2 \mathrm{H}), 1.85-1.69(\mathrm{~m}, 2 \mathrm{H}) .{ }^{13} \mathrm{C} \mathrm{NMR}\left(75 \mathrm{MHz}, \mathrm{CDCl}_{3}\right) \delta 167.79,155.00$, 105.49, 66.36, 50.83, 20.98, 19.10. EI-MS m/z $142(\mathrm{M})$.

\subsection{General Procedure for Synthesizing Compounds 1-8, Using $\mathbf{1}$ as an Example}

\subsubsection{Compound 1}

To a suspension of lithium aluminum hydride $(0.76 \mathrm{~g}, 20 \mathrm{mmol})$ in ether $(30 \mathrm{~mL})$ in an ice water bath was added dropwise a solution of methyl 3,4-dihydro-2H-pyran-5-carboxylate (1.88 g, $13.2 \mathrm{mmol}, 3.2$ molar equivalents with respect to phloroglucinol) in ether $(20 \mathrm{~mL})$. The resultant mixture was allowed to warm to room temperature and stirred for one additional hour. A $2 \mathrm{M}$ aqueous sodium hydroxide $(1.2 \mathrm{~g})$ solution was then added at $0{ }^{\circ} \mathrm{C}$. The resultant mixture was filtered and washed with ether $(3 \times 50 \mathrm{~mL})$, and the combined filtrates were concentrated in vacuo below $10{ }^{\circ} \mathrm{C}$ to afford the reduction product as a colorless liquid. This material was diluted with ether $(20 \mathrm{~mL})$ and immediately used in subsequent experiments, because it is unstable.

To a suspension of phloroglucinol $(0.52 \mathrm{~g}, 4.1 \mathrm{mmol})$ and anhydrous magnesium sulfate $(2 \mathrm{~g})$ in $40 \mathrm{~mL}$ ether at $0{ }^{\circ} \mathrm{C}$ was added the ether solution prepared above. $p$-Toluene sulfonic acid $(0.1 \mathrm{~g})$ was added after stirring for 1 minute. The resultant mixture was warmed to room temperature and stirred for $30 \mathrm{~min}$. The reaction mixture was then filtered, and the filter cake was washed with ether $(3 \times 50 \mathrm{~mL})$. The combined filtrates were washed with water $(100 \mathrm{~mL})$ and saturated brine $(100 \mathrm{~mL})$ before drying over anhydrous magnesium sulfate and concentrating in vacuo. Purification via flash chromatography eluting with ether:dichloromethane (2:25) or ethyl acetate:petroleum ether (1:20-1:5) afforded a colorless crystal $(0.95 \mathrm{~g}, 3.0 \mathrm{mmol}, 73 \%$ yield $)$ as a diastereoisomeric mixture of $( \pm)-1 \mathrm{a}$ and $( \pm)-1 \mathbf{b}(\sim 1: 1) .{ }^{1} \mathrm{H}$ NMR $\left(400 \mathrm{MHz}, \mathrm{CDCl}_{3}\right) \delta 6.03(\mathrm{~s}, 1 \mathrm{H}), 5.42(\mathrm{~s}, 1 \mathrm{H}), 5.30(\mathrm{t}, J=3.1 \mathrm{~Hz}, 1 \mathrm{H}), 5.23$ (t, $J=3.1 \mathrm{~Hz}, 1 \mathrm{H}), 4.07-3.93(\mathrm{~m}, 2 \mathrm{H}), 3.79-3.63(\mathrm{~m}, 2 \mathrm{H}), 2.79-2.51(\mathrm{~m}, 4 \mathrm{H}), 2.23-2.07(\mathrm{~m}, 2 \mathrm{H})$, $1.73-1.59(\mathrm{~m}, 8 \mathrm{H}) .{ }^{13} \mathrm{C}$ NMR $\left(101 \mathrm{MHz}, \mathrm{CDCl}_{3}\right) \delta 152.75,152.71,151.62,151.54,151.16,151.12$, $100.50,100.41,100.05,100.00,96.74,96.68,96.65,95.70,63.13,62.96,62.84,62.57,31.24,31.20$, $31.11,31.08,24.56,24.43,24.25,24.14,23.55,23.41,23.31,22.93,22.69,22.54$. EI-MS m/z 318 (M). EI-HR-MS m/z found: 318.1457 ; calcd. for $\mathrm{C}_{18} \mathrm{H}_{22} \mathrm{O}_{5}: 318.1462$.

\subsubsection{Compound 2}

The title compound was obtained as a colorless crystal in 55\% yield as a diastereoisomeric mixture of $( \pm)-\mathbf{2 a}$ and $( \pm)-\mathbf{2 b}(\sim 1: 1) .{ }^{1} \mathrm{H}$ NMR $\left(400 \mathrm{MHz} \mathrm{CDCl}_{3}\right) \delta 6.34(\mathrm{~s}, 1 \mathrm{H}), 5.26-5.16(\mathrm{~m}, 2 \mathrm{H}), 4.07-3.92$ (m, 2H), 3.75-3.60 (m, 2H), 2.81-2.65 (m, 2H), 2.62-2.41 (m, 2H), 2.19-2.10 (m, 2H), $2.04(\mathrm{~s}, 3 \mathrm{H})$, $1.75-1.53(\mathrm{~m}, 8 \mathrm{H}) .{ }^{13} \mathrm{C}$ NMR $\left(101 \mathrm{MHz}, \mathrm{CDCl}_{3}\right) \delta 151.57,135.30,111.44,111.42,101.78,95.95$, $62.64,62.51,60.17,31.73,31.67,26.67,26.56,24.45,24.35,23.35,23.25,14.37,14.03$. EI-MS $\mathrm{m} / \mathrm{z}$ 316 (M). EI-HR-MS m/z found: 316.1667; calcd. for $\mathrm{C}_{19} \mathrm{H}_{24} \mathrm{O}_{4}: 316.1669$. 


\subsubsection{Compound 3}

The title compound was obtained as a colorless crystal in 55\% yield as a diastereoisomeric mixture of $( \pm)$-3a and $( \pm)$-3b $(\sim 1: 1) .{ }^{1} \mathrm{H}$ NMR $\left(400 \mathrm{MHz}, \mathrm{CDCl}_{3}\right) \delta 14.03(\mathrm{~s}, 1 \mathrm{H}), 5.40-5.33(\mathrm{~m}, 2 \mathrm{H})$, 4.05-3.87 (m, 2H), 3.82-3.65 (m, 2H), 2.77-2.51 (m, 7H), 2.23-2.11 (m, 2H), 1.79-1.53 (m, 8H). ${ }^{13} \mathrm{C}$ NMR $\left(101 \mathrm{MHz}, \mathrm{CDCl}_{3}\right) \delta 203.34,162.43,162.39,157.04,156.97,153.71,153.59,105.18$, $100.37,100.28,98.58,98.48,97.47,97.20,62.71,62.62,62.46,62.34,33.08,30.98,30.91,30.74$, $30.66,23.95,23.89,23.79,23.69,23.49,23.38,23.28,22.75,22.42$. EI-MS $\mathrm{m} / z \quad 360$ (M). EI-HR-MS $m / z$ found: 360.1565 ; calcd. for $\mathrm{C}_{20} \mathrm{H}_{24} \mathrm{O}_{6}: 360.1567$.

\subsubsection{Compound 4}

The title compound was obtained as a colorless crystal in $60 \%$ yield as a diastereoisomeric mixture of $( \pm)-\mathbf{4 a}$ and $( \pm)-\mathbf{4 b}(\sim 1: 1) .{ }^{1} \mathrm{H}$ NMR $\left(400 \mathrm{MHz}, \mathrm{CDCl}_{3}\right) \delta 13.02(\mathrm{~s}, 1 \mathrm{H}), 7.52(\mathrm{~d}, J=8.9 \mathrm{~Hz}, 1 \mathrm{H})$, $6.43(\mathrm{~d}, J=8.9 \mathrm{~Hz}, 1 \mathrm{H}), 5.36(\mathrm{~d}, J=2.6 \mathrm{~Hz}, 1 \mathrm{H}), 4.03-3.93(\mathrm{~m}, 1 \mathrm{H}), 3.80-3.69(\mathrm{~m}, 1 \mathrm{H}), 2.80-2.65$ $(\mathrm{m}, 2 \mathrm{H}), 2.54(\mathrm{~s}, 3 \mathrm{H}), 2.26-2.15(\mathrm{~m}, 1 \mathrm{H}), 1.78-1.53(\mathrm{~m}, 4 \mathrm{H}) .{ }^{13} \mathrm{C} \mathrm{NMR}\left(101 \mathrm{MHz}, \mathrm{CDCl}_{3}\right) \delta 202.73$, 162.65, 159.49, 129.83, 113.53, 108.24, 108.12, 97.10, 62.54, 30.82, 26.08, 23.98, 23.61, 22.78. EI-MS $m / z 248$ (M). EI-HR-MS $m / z$ found: 248.1041; calcd. for $\mathrm{C}_{14} \mathrm{H}_{16} \mathrm{O}_{4}: 248.1043$.

\subsubsection{Compound 5}

The title compound was obtained as a colorless crystal in $71 \%$ yield as a diastereoisomeric mixture of $( \pm)-5 \mathbf{a}$ and $( \pm)-5 \mathbf{b}(\sim 1: 1) .{ }^{1} \mathrm{H}$ NMR $\left(400 \mathrm{MHz} \mathrm{CDCl}_{3}\right) \delta 6.51(\mathrm{~s}, 1 \mathrm{H}), 5.28(\mathrm{~d}, J=2.6 \mathrm{~Hz}, 2 \mathrm{H}), 5.26$ $(\mathrm{d}, J=2.6 \mathrm{~Hz}, 1 \mathrm{H}), 4.05-3.92(\mathrm{~m}, 2 \mathrm{H}), 3.88(\mathrm{~s}, 3 \mathrm{H}), 3.75-3.57(\mathrm{~m}, 2 \mathrm{H}), 2.93-2.39(\mathrm{~m}, 4 \mathrm{H})$, 2.19-2.06 (m, 2H), 1.71-1.57 (m, 8H). $\left.{ }^{13} \mathrm{C} \mathrm{NMR} \mathrm{(101} \mathrm{MHz,} \mathrm{CDCl}_{3}\right) \delta 168.96,152.36,152.17,133.34$, 130.83, 128.83, 110.87, 110.79, 105.76, 96.43, 96.33, 65.50, 62.76, 62.34, 60.30, 51.83, 31.54, 31.45, 26.83, 26.27, 24.19, 23.96, 23.55, 23.27. EI-MS m/z 360 (M). EI-HR-MS $m / z$ found: 360.1566; calcd. for $\mathrm{C}_{20} \mathrm{H}_{24} \mathrm{O}_{6}: 360.1567$.

\subsubsection{Compound 6}

The title compound was obtained as a colorless crystal in $80 \%$ yield as a diastereoisomeric mixture of $( \pm)-6 \mathbf{a}$ and $( \pm)-6 \mathbf{b}(\sim 1: 1) .{ }^{1} \mathrm{H}$ NMR $\left(400 \mathrm{MHz}, \mathrm{CDCl}_{3}\right) \delta 12.48(\mathrm{~s}, 1 \mathrm{H}), 1 \mathrm{H} \mathrm{NMR}(400 \mathrm{MHz}$, $\mathrm{CDCl} 3) \delta 12.48(\mathrm{~s}, 2 \mathrm{H}), 5.53(\mathrm{~d}, J=2.5 \mathrm{~Hz}, 1 \mathrm{H}), 5.52(\mathrm{~d}, J=2.5 \mathrm{~Hz}, 1 \mathrm{H}), 5.37(\mathrm{~d}, J=2.6 \mathrm{~Hz}, 1 \mathrm{H})$, $5.35(\mathrm{~d}, J=2.6 \mathrm{~Hz}, 1 \mathrm{H}), 4.05-3.64(\mathrm{~m}, 8 \mathrm{H}), 2.88-2.51(\mathrm{~m}, 8 \mathrm{H}), 2.37-2.10(\mathrm{~m}, 4 \mathrm{H})$, 1.79-1.51 (m, 16H). ${ }^{13} \mathrm{C}$ NMR $\left(101 \mathrm{MHz}, \mathrm{CDCl}_{3}\right) \delta 171.17,161.28,161.24,156.46,156.38,151.02$, $150.91,101.93,101.82,98.94,98.85,98.83,97.55,97.49,94.06,94.03,62.90,62.54,62.48,62.42$, $30.89,30.81,30.75,30.66,23.98,23.81,23.78,23.74,23.55,23.41,23.40,23.32,22.77,22.39$.

Compound 6 was purified via flash chromatography (petro ether:ethyl acetate $=50: 1-30: 1$ ) followed by crystallization to afford the pure isomers $( \pm)-\mathbf{6 a}$ and $( \pm)-6 \mathbf{b}$ :

( \pm )-6a: m.p. $171.2-172.1{ }^{\circ} \mathrm{C} .{ }^{1} \mathrm{H}$ NMR $\left(400 \mathrm{MHz}, \mathrm{CDCl}_{3}\right) \delta 12.47(\mathrm{~s}, 1 \mathrm{H}), 11.31(\mathrm{~s}, 1 \mathrm{H})$, $5.51(\mathrm{~d}, J=2.4 \mathrm{~Hz}, 1 \mathrm{H}), 5.35(\mathrm{~d}, J=2.4 \mathrm{~Hz}, 1 \mathrm{H}), 4.05-3.67(\mathrm{~m}, 4 \mathrm{H}), 2.87-2.53(\mathrm{~m}, 4 \mathrm{H})$, 2.39-2.10 (m, 2H), 1.87-1.48 (m, 8H). $\left.{ }^{13} \mathrm{C} \mathrm{NMR} \mathrm{(101} \mathrm{MHz,} \mathrm{CDCl}_{3}\right) \delta 171.14,161.24,156.37,150.91$, 
101.93, 98.94, 98.84, 97.55, 94.06, 62.89, 62.54, 30.89, 30.67, 23.99, 23.73, 23.56, 23.39, $23.32,22.39$.

(土)-6b: m.p. $178.4-179.5{ }^{\circ} \mathrm{C} .{ }^{1} \mathrm{H}$ NMR $\left(400 \mathrm{MHz}, \mathrm{CDCl}_{3}\right) \delta 12.47(\mathrm{~s}, 1 \mathrm{H}), 11.31(\mathrm{~s}, 1 \mathrm{H})$, $5.53(\mathrm{~d}, J=2.4 \mathrm{~Hz}, 1 \mathrm{H}), 5.37(\mathrm{~d}, J=2.8 \mathrm{~Hz}, 1 \mathrm{H}), 3.99-3.68(\mathrm{~m}, 4 \mathrm{H}), 2.82-2.56(\mathrm{~m}, 4 \mathrm{H})$, 2.32-2.13 (m, 2H), 1.81-1.52 (m, 8H). $\left.{ }^{13} \mathrm{C} \mathrm{NMR} \mathrm{(101} \mathrm{MHz,} \mathrm{CDCl}_{3}\right) \delta 171.15,161.28,156.45,151.01$, $101.82,98.86,97.50,94.04,62.48,62.42,30.81,30.76,23.79,23.54,23.40,22.76$.

Crystallographic data for $( \pm)-6 a$ : Single-crystal growth was performed in EtOAc at room temperature. $\mathrm{C}_{19} \mathrm{H}_{22} \mathrm{O}_{7}$, crystal dimension $0.42 \mathrm{~mm} \times 0.40 \mathrm{~mm} \times 0.37 \mathrm{~mm}$, space group monoclinic, $C 2 / c$; unit cell dimensions, $a=25.4092$ (3) $\AA, b=12.9938$ (2) $\AA, c=10.67030$ (10) $\AA$, volume $=3279.17$ (7) $\AA^{3}, Z=8, D_{\text {calcd }}=1.468 \mathrm{Mg} / \mathrm{m}^{3}, m=0.939 \mathrm{~mm}^{-1}, F 000=1,536$. All single-crystal data were collected via the hemisphere technique on a Bruker SMART $1000 \mathrm{CCD}$ system diffractometer with graphite-monochromated Mo Ká radiation $\ddot{e}=1.54178$ at $150(2) \mathrm{K}$. The structure was solved using the direct method. The final $R$ value was 0.0322 , wR2 $=0.0791[I>2 o ́(I)]$. More details are provided in the Supplementary Information.

\subsubsection{Compound 7}

The title compound was obtained as a colorless crystal in $90 \%$ yield as a diastereoisomeric mixture of $( \pm)-7 \mathbf{a}$ and $( \pm)-7 \mathbf{b}(\sim 1: 1) .{ }^{1} \mathrm{H}$ NMR $\left(400 \mathrm{MHz}, \mathrm{CDCl}_{3}\right) \delta 11.97(\mathrm{~s}, 1 \mathrm{H}), 11.96(\mathrm{~s}, 1 \mathrm{H})$, 5.34 (apparent t, 2H), $5.32(\mathrm{~d}, J=2.6 \mathrm{~Hz}, 1 \mathrm{H}), 5.30(\mathrm{~d}, J=2.6 \mathrm{~Hz}, 1 \mathrm{H}), 4.17-3.93(\mathrm{~m}, 4 \mathrm{H})$, $3.91(\mathrm{~s}, 6 \mathrm{H}), 3.83-3.62(\mathrm{~m}, 4 \mathrm{H}), 2.87-2.43(\mathrm{~m}, 8 \mathrm{H}), 2.25-2.01(\mathrm{~m}, 4 \mathrm{H}), 1.77-1.58(\mathrm{~m}, 16 \mathrm{H}) .{ }^{13} \mathrm{C} \mathrm{NMR}$ $\left(101 \mathrm{MHz} \mathrm{CDCl}_{3}\right) \delta 172.01,160.67,160.65,156.01,155.95,152.77,152.64,100.16,100.08,99.43$, $99.32,97.38,97.32,97.00,96.97,95.79,95.77,62.93,62.69,62.37,52.03,31.05,30.99,30.47,30.44$, 24.20, 24.02, 23.90, 23.69, 23.51, 23.40, 23.25, 23.01, 22.76, 22.71, 22.55. EI-MS m/z 376 (M). EI-HR-MS m/z found: 376.1513 ; calcd. for $\mathrm{C}_{20} \mathrm{H}_{24} \mathrm{O}_{7}: 376.1517$.

\subsubsection{Compound $\mathbf{8}$}

A solution of $6(0.2 \mathrm{~g}, 0.6 \mathrm{mmol})$ and diethylamine $(0.2 \mathrm{~g}, 6 \mathrm{mmol})$ in acetone $(20 \mathrm{~mL})$ was stirred at room temperature for $30 \mathrm{~min}$. The acetone and excess diethylamine were removed under reduced pressure on a rotary evaporator to afford the title compound as a white foam as a diastereoisomeric mixture of $( \pm)-8 \mathbf{a}$ and $( \pm)-8 \mathbf{b}(\sim 1: 1) .{ }^{1} \mathrm{H}$ NMR $\left(400 \mathrm{MHz}, \mathrm{CDCl}_{3}\right) \delta 5.31(\mathrm{~d}, J=2.5 \mathrm{~Hz}, 1 \mathrm{H}), 5.25(\mathrm{t}$, $J=2.8 \mathrm{~Hz}, 1 \mathrm{H}), 4.13-3.90(\mathrm{~m}, 2 \mathrm{H}), 3.76-3.54(\mathrm{~m}, 2 \mathrm{H}), 3.00$ (q, $J=7.3 \mathrm{~Hz}, 4 \mathrm{H}), 2.74-2.54(\mathrm{~m}, 4 \mathrm{H})$, $2.16(\mathrm{~s}, 1 \mathrm{H}), 2.15-2.08(\mathrm{~m}, 2 \mathrm{H}), 1.79-1.54(\mathrm{~m}, 8 \mathrm{H}), 1.29(\mathrm{t}, J=7.3 \mathrm{~Hz}, 6 \mathrm{H})$.

\subsection{Typical Method of Etherification of $\mathbf{1}$ to Prepare 9-20, Using 9 as an Example}

\subsubsection{Compound 9}

A solution of $1(0.1 \mathrm{~g}, 0.31 \mathrm{mmol})$, potassium carbonate $(87 \mathrm{mg}, 0.62 \mathrm{mmol})$ and dimethyl sulfate (78 mg, $0.62 \mathrm{mmol}$ ) was stirred in acetone $(15 \mathrm{~mL})$ at $60{ }^{\circ} \mathrm{C}$ and monitored via thin layer chromatography. The resultant mixture was allowed to cool to room temperature before pouring into water $(50 \mathrm{~mL})$. The aqueous layer was extracted with ethyl acetate $(3 \times 40 \mathrm{~mL})$. The combined organic 
layers were washed with saturated brine $(50 \mathrm{~mL})$, dried over anhydrous magnesium sulfate and concentrated in vacuo. Purification via flash chromatography using ethyl acetate:petroleum ether (1:20) as the eluant afforded colorless crystals $(87 \mathrm{mg}, 0.26 \mathrm{mmol}, 85 \%$ yield) that were a mixture of diastereoisomers $( \pm)-9 \mathbf{a}$ and $( \pm)-9 \mathbf{b}(\sim 1: 1) .{ }^{1} \mathrm{H} \mathrm{NMR}\left(400 \mathrm{MHz}, \mathrm{CDCl}_{3}\right) \delta 6.07(\mathrm{~s}, 1 \mathrm{H}), 5.28$ (t, $J=2.9 \mathrm{~Hz}, 1 \mathrm{H}), 5.24(\mathrm{t}, J=3.3 \mathrm{~Hz}, 1 \mathrm{H}), 4.09-3.91(\mathrm{~m}, 2 \mathrm{H}), 3.74(\mathrm{~s}, 3 \mathrm{H}), 3.74-3.66(\mathrm{~m}, 2 \mathrm{H})$, 2.80-2.47 (m, 4H), 2.23-2.07 (m, 2H), 1.74-1.58 (m, 8H). ${ }^{13} \mathrm{C}$ NMR (101 MHz, $\left.\mathrm{CDCl}_{3}\right) \delta 156.56$, 156.52 , 151.66, 151.58, 150.82, 101.10, 101.04, 100.37, 100.28, 96.74, 96.72, 96.66, 91.81, 63.09, $62.92,62.83,62.52,55.33,31.22,31.18,31.07,31.03,24.57,24.44,24.25,24.14,23.57,23.41,23.33$, 23.04, 22.74, 22.69, 22.54. EI-MS $\mathrm{m} / z 332$ (M). EI-HR-MS $\mathrm{m} / z$ found: 332.1621; calcd. for $\mathrm{C}_{19} \mathrm{H}_{24} \mathrm{O}_{5}: 332.1618$.

\subsubsection{Compound 10}

The title compound was obtained as a colorless crystal in $82 \%$ yield as a diastereoisomeric mixture of $( \pm)-\mathbf{1 0 a}$ and $( \pm)-\mathbf{1 0 b}(\sim 1: 1) .{ }^{1} \mathrm{H}$ NMR $\left(400 \mathrm{MHz}, \mathrm{CDCl}_{3}\right) \delta 5.94(\mathrm{~s}, 1 \mathrm{H}), 5.29(\mathrm{t}, J=3.0 \mathrm{~Hz}, 1 \mathrm{H})$, $5.23(\mathrm{dd}, J=4.7,2.5 \mathrm{~Hz}, 1 \mathrm{H}), 4.54(\mathrm{~s}, 2 \mathrm{H}), 4.25(\mathrm{q}, J=7.1 \mathrm{~Hz}, 2 \mathrm{H}), 4.08-3.90(\mathrm{~m}, 2 \mathrm{H})$, 3.80-3.60 (m, 2H), 2.83-2.50 (m, 4H), $2.18(\mathrm{~d}, J=27.6 \mathrm{~Hz}, 2 \mathrm{H}), 1.78-1.59(\mathrm{~m}, 8 \mathrm{H})$, $1.30(\mathrm{t}, J=7.1 \mathrm{~Hz}, 3 \mathrm{H}) .{ }^{13} \mathrm{C}$ NMR $\left(101 \mathrm{MHz}, \mathrm{CDCl}_{3}\right) \delta 168.83,154.88,154.83,151.60,151.51$, $151.12,151.09,101.87,101.81,101.50,101.41,96.83,96.76,96.72,96.66,92.81,65.49,63.06,62.87$, $62.81,62.52,61.16,31.19,31.15,31.06,31.03,24.56,24.41,24.22,24.10,23.56,23.41,23.32,23.01$, 22.74, 22.58, 14.10. EI-MS $m / z \quad 404$ (M). EI-HR-MS $m / z$ found: 404.1833; calcd. for $\mathrm{C}_{22} \mathrm{H}_{28} \mathrm{O}_{7}: 404.1830$.

\subsubsection{Compound 11}

The title compound was obtained as a colorless crystal in $82 \%$ yield as a diastereoisomeric mixture of $( \pm)-\mathbf{1 1 a}$ and $( \pm)-\mathbf{1 1 b}(\sim 1: 1) .{ }^{1} \mathrm{H}$ NMR $\left(400 \mathrm{MHz}, \mathrm{CDCl}_{3}\right) \delta 6.11(\mathrm{~s}, J=7.6 \mathrm{~Hz}, 1 \mathrm{H})$, $5.57-5.41(\mathrm{~m}, 1 \mathrm{H}), 5.30(\mathrm{t}, J=2.8 \mathrm{~Hz}, 1 \mathrm{H}), 5.28-5.24(\mathrm{~m}, 1 \mathrm{H}), 4.46(\mathrm{~d}, J=6.5 \mathrm{~Hz}, 2 \mathrm{H})$, 4.12-3.93 (m, 2H), 3.81-3.61 (m, 2H), 2.85-2.52 (m, 4H), 2.24-2.08 (m, 2H), 1.73-1.61 (m, 8H), $1.58(\mathrm{~s}, 6 \mathrm{H}) .{ }^{13} \mathrm{C}$ NMR $\left(101 \mathrm{MHz}, \mathrm{CDCl}_{3}\right) \delta 155.88,155.83,151.57,151.50,150.84,150.81,137.13$, $120.10,101.52,101.46,100.32,100.23,96.79,96.73,96.67,92.98,65.04,63.07,62.92,62.82,62.53$, $31.29,31.25,31.13,25.70,24.62,24.50,24.30,24.19,23.59,23.43,23.35,23.13,22.84,22.70,22.56$, 18.16. EI-MS $m / z 386$ (M). EI-HR-MS $m / z$ found: 386.2086; calcd. for $\mathrm{C}_{23} \mathrm{H}_{30} \mathrm{O}_{5}: 386.2088$.

\subsubsection{Compound 12}

The title compound was obtained by reaction in a sealed tube as a colorless crystal in $74 \%$ yield as a diastereoisomeric mixture of $( \pm)-\mathbf{1 2 a}$ and $( \pm)-\mathbf{1 2 b}(\sim 1: 1) .{ }^{1} \mathrm{H}$ NMR $\left(400 \mathrm{MHz}, \mathrm{CDCl}_{3}\right)$ $\delta 6.06(\mathrm{~s}, J=7.1 \mathrm{~Hz}, 1 \mathrm{H}), 6.09-5.97(\mathrm{~m}, 1 \mathrm{H}), 5.40(\mathrm{ddd}, J=17.3,3.2,1.6 \mathrm{~Hz}, 1 \mathrm{H}), 5.29(\mathrm{t}, J=2.8 \mathrm{~Hz}$, $1 \mathrm{H}), 5.28-5.22(\mathrm{~m}, 1 \mathrm{H}), 5.24(\mathrm{t}, J=3.0 \mathrm{~Hz}, 1 \mathrm{H}), 4.46(\mathrm{dt}, J=5.0,1.4 \mathrm{~Hz}, 2 \mathrm{H}), 4.10-3.91(\mathrm{~m}, 2 \mathrm{H})$, $3.81-3.63(\mathrm{~m}, 2 \mathrm{H}), 2.86-2.46(\mathrm{~m}, 4 \mathrm{H}), 2.22-2.08(\mathrm{~m}, 2 \mathrm{H}), 1.80-1.59 \quad(\mathrm{~m}, 8 \mathrm{H}) .{ }^{13} \mathrm{C} \quad \mathrm{NMR}$ $\left(101 \mathrm{MHz}, \mathrm{CDCl}_{3}\right) \delta 155.51,155.47,151.56,151.48,150.89,150.85,133.41,117.03,101.48,101.42$, $100.56,100.47,96.78,96.71,96.68,92.94,68.67,63.16,63.00,62.85,62.55,31.21,31.17,31.11$, 
31.07, 24.60, 24.48, 24.28, 24.16, 23.59, 23.42, 23.39, 23.31, 23.13, 22.84, 22.66, 22.51. EI-MS $m / z 358$ (M). EI-HR-MS m/z found: 358.1767; calcd. for $\mathrm{C}_{21} \mathrm{H}_{26} \mathrm{O}_{5}: 358.1775$.

\subsubsection{Compound $\mathbf{1 3}$}

The title compound was obtained by reaction in a sealed tube as a colorless crystal in $97 \%$ yield as a diastereoisomeric mixture of $( \pm)$-13a and $( \pm)-\mathbf{1 3 b}(\sim 1: 1) .{ }^{1} \mathrm{H}$ NMR $\left(400 \mathrm{MHz}, \mathrm{CDCl}_{3}\right) \delta 6.05(\mathrm{~s}, 1 \mathrm{H})$, $5.28(\mathrm{t}, J=2.8 \mathrm{~Hz}, 1 \mathrm{H}), 5.24(\mathrm{t}, J=3.1 \mathrm{~Hz}, 1 \mathrm{H}), 4.06-3.95(\mathrm{~m}, 2 \mathrm{H}), 3.85(\mathrm{t}, J=6.4 \mathrm{~Hz}, 2 \mathrm{H})$, 3.77-3.62 (m, 2H), 2.83-2.47 (m, 4H), 2.23-2.07 (m, 2H), 1.84-1.72 (m, 2H), 1.73-1.59 (m, 8H), $1.01(\mathrm{t}, J=7.4 \mathrm{~Hz}, 3 \mathrm{H}) .{ }^{13} \mathrm{C} \mathrm{NMR}\left(101 \mathrm{MHz}, \mathrm{CDCl}_{3}\right) \delta 155.93,155.89,151.52,151.45,150.73$, $150.69,101.29,101.23,100.05,99.96,96.70,96.62,96.56,92.53,69.29,62.96,62.81,62.44,31.19$, $31.14,31.07,31.03,24.49,24.37,24.23,24.11,23.55,23.38,23.31,23.03,22.72,22.65,22.51,22.45$, 10.53. EI-MS $m / z 360$ (M). EI-HR-MS $m / z$ found: 360.1935 ; calcd. for $\mathrm{C}_{21} \mathrm{H}_{28} \mathrm{O}_{5}: 360.1931$.

\subsubsection{Compound 14}

The title compound was obtained as a colorless crystal in $61 \%$ yield as a diastereoisomeric mixture of $( \pm)-14 \mathbf{a}$ and $( \pm)-\mathbf{1 4 b}(\sim 1: 1) .{ }^{1} \mathrm{H} \mathrm{NMR}\left(400 \mathrm{MHz}, \mathrm{CDCl}_{3}\right) \delta 6.07(\mathrm{~s}, 1 \mathrm{H}), 5.28(\mathrm{t}, J=2.8 \mathrm{~Hz}, 1 \mathrm{H})$, $5.24(\mathrm{t}, J=2.8 \mathrm{~Hz}, 1 \mathrm{H}), 4.11-3.96(\mathrm{~m}, 2 \mathrm{H}), 3.91(\mathrm{t}, J=6.6 \mathrm{~Hz}, 2 \mathrm{H}), 3.76-3.64(\mathrm{~m}, 2 \mathrm{H}), 2.78-2.49$ (m, 4H), 2.24-2.05 (m, 2H), 1.87-1.73 (m, 1H), 1.74-1.59 (m, 10H), 0.95 (dd, J=6.6, 0.8 Hz, 6H). ${ }^{13} \mathrm{C} \mathrm{NMR}\left(101 \mathrm{MHz}, \mathrm{CDCl}_{3}\right) \delta 170.61,161.36,161.32,154.30,154.22,150.78,150.68,141.49$, $126.87,125.28,123.72,101.33,101.24,98.04,97.94,97.50,97.25,97.18,96.48,62.84,62.42,62.34$, $62.21,40.71,31.01,30.92,30.71,30.63,29.78,29.64,24.10,23.90,23.78,23.62,23.49,23.38,23.33$, 22.88, 22.50. EI-MS $m / z 388$ (M). EI-HR-MS $m / z$ found: 388.2245 ; calcd. for $\mathrm{C}_{23} \mathrm{H}_{32} \mathrm{O}_{5}: 388.2244$.

\subsubsection{Compound 15}

The title compound was obtained as a colorless crystal in $75 \%$ yield as a diastereoisomeric mixture of $( \pm)$-15a and $( \pm)-\mathbf{1 5 b}(\sim 1: 1) .{ }^{1} \mathrm{H} \mathrm{NMR}\left(400 \mathrm{MHz}, \mathrm{CDCl}_{3}\right) \delta 6.04(\mathrm{~s}, 1 \mathrm{H}), 5.28(\mathrm{t}, J=2.7 \mathrm{~Hz}, 1 \mathrm{H})$, $5.24(\mathrm{t}, J=3.1 \mathrm{~Hz}, 1 \mathrm{H}), 4.14(\mathrm{q}, J=7.1 \mathrm{~Hz}, 2 \mathrm{H}), 4.08-3.97(\mathrm{~m}, 2 \mathrm{H}), 3.92(\mathrm{t}, J=6.1 \mathrm{~Hz}, 2 \mathrm{H})$, $3.78-3.65(\mathrm{~m}, 2 \mathrm{H}), 2.82-2.52(\mathrm{~m}, 4 \mathrm{H}), 2.49(\mathrm{t}, J=7.4 \mathrm{~Hz}, 2 \mathrm{H}), 2.24-2.05(\mathrm{~m}, 4 \mathrm{H}), 1.65(\mathrm{~m}, 8 \mathrm{H}), 1.26$ $(\mathrm{t}, J=7.1 \mathrm{~Hz}, 3 \mathrm{H}) .{ }^{13} \mathrm{C} \mathrm{NMR}\left(101 \mathrm{MHz}, \mathrm{CDCl}_{3}\right) \delta 173.13,155.70,151.68,151.61,150.91,101.38$, $101.33,100.49,100.40,96.80,96.73,96.68,92.65,66.72,63.04,62.89,62.55,60.38,31.28,31.24$, 31.16, 30.98, 24.65, 24.59, 24.47, 24.33, 24.22, 23.62, 23.46, 23.39, 23.10, 22.82, 22.74, 22.61, 14.20. EI-MS $m / z 432$ (M). EI-HR-MS m/z found: 432.2151; calcd. for $\mathrm{C}_{24} \mathrm{H}_{32} \mathrm{O}_{7}: 432.2143$.

\subsubsection{Compound 16}

The title compound was obtained as a colorless crystal in $71 \%$ yield as a diastereoisomeric mixture of $( \pm)$-16a and $( \pm)$-16b $(\sim 1: 1) .{ }^{1} \mathrm{H}$ NMR $\left(400 \mathrm{MHz}, \mathrm{CDCl}_{3}\right) \delta 6.08(\mathrm{~s}, 1 \mathrm{H}), 5.27(\mathrm{t}, J=2.8 \mathrm{~Hz}, 1 \mathrm{H})$, $5.24(\mathrm{t}, J=3.1 \mathrm{~Hz}, 1 \mathrm{H}), 4.05(\mathrm{t}, J=5.8 \mathrm{~Hz}, 2 \mathrm{H}), 4.00(\mathrm{~m}, 2 \mathrm{H}), 3.84(\mathrm{t}, J=5.9 \mathrm{~Hz}, 2 \mathrm{H})$, 3.78-3.62 (m, 2H), 2.82-2.45 (m, 4H), 2.25-2.07 (m, 2H), 2.06-2.01 (m, 2H), 1.76-1.54 (m, 8H). ${ }^{13} \mathrm{C}$ NMR $\left(101 \mathrm{MHz}, \mathrm{CDCl}_{3}\right) \delta 155.61,155.57,151.68,151.61,150.90,150.85,145.18,128.49$, 128.08, 101.14, 101.07, 100.67, 100.58, 96.74, 96.72, 96.67, 92.59, 66.06, 63.08, 62.93, 62.61, 60.93, 
31.89, 31.20, 31.15, 31.05, 31.01, 29.67, 28.38, 28.27, 24.53, 24.42, 24.31, 24.18, 23.54, 23.41, 23.36, 23.15, 22.85, 22.69, 22.57. EI-MS $m / z 376$ (M). EI-HR-MS $\mathrm{m} / \mathrm{z}$ found: 376.1885; calcd. for $\mathrm{C}_{21} \mathrm{H}_{28} \mathrm{O}_{6}: 376.1880$.

\subsubsection{Compound 17}

The title compound was obtained as a colorless crystal in $72 \%$ yield as a diastereoisomeric mixture of $( \pm)-17 \mathbf{a}$ and $( \pm)-\mathbf{1 7 b}(\sim 1: 1) .{ }^{1} \mathrm{H}$ NMR $\left(400 \mathrm{MHz}, \mathrm{CDCl}_{3}\right) \delta 6.05(\mathrm{~s}, 1 \mathrm{H}), 5.28(\mathrm{t}, J=2.8 \mathrm{~Hz}, 1 \mathrm{H})$, $5.24(\mathrm{t}, J=3.1 \mathrm{~Hz}, 1 \mathrm{H}), 4.12-3.95(\mathrm{~m}, 2 \mathrm{H}), 3.88(\mathrm{t}, J=6.5 \mathrm{~Hz}, 2 \mathrm{H}), 3.78-3.60(\mathrm{~m}, 2 \mathrm{H})$, 2.85-2.48 (m, 4H), $2.14(\mathrm{~m}, 2 \mathrm{H}), 1.75-1.60(\mathrm{~m}, 8 \mathrm{H}), 1.43-1.17(\mathrm{~m}, 10 \mathrm{H}), 0.89(\mathrm{t}, J=6.9 \mathrm{~Hz}, 3 \mathrm{H})$. ${ }^{13} \mathrm{C}$ NMR $\left(101 \mathrm{MHz}, \mathrm{CDCl}_{3}\right) \delta 156.08,156.05,151.65,151.57,150.85,150.81,101.40,101.34$, $100.16,100.06,96.80,96.73,96.67,92.67,67.96,63.03,62.88,62.79,62.49,31.77,31.33,31.28$, $31.22,31.18,29.18,28.99,26.06,24.61,24.48,24.32,24.21,23.66,23.49,23.40,23.18,22.89,22.76$, 22.58, 14.03. EI-MS $m / z 416$ (M). EI-HR-MS $m / z$ found: 416.2547 ; calcd. for $\mathrm{C}_{25} \mathrm{H}_{36} \mathrm{O}_{5}: 416.2557$.

\subsubsection{Compound 18}

The title compound was obtained as a colorless crystal in $70 \%$ yield as a diastereoisomeric mixture of $( \pm)$-18a and $( \pm)-\mathbf{1 8 b}(\sim 1: 1) .{ }^{1} \mathrm{H} \mathrm{NMR}\left(400 \mathrm{MHz}, \mathrm{CDCl}_{3}\right) \delta 7.30(\mathrm{~d}, J=8.0 \mathrm{~Hz}, 2 \mathrm{H})$, $7.18(\mathrm{~d}, J=7.9 \mathrm{~Hz}, 2 \mathrm{H}), 6.15(\mathrm{~s}, 1 \mathrm{H}), 5.29(\mathrm{t}, J=3.0 \mathrm{~Hz}, 1 \mathrm{H}), 5.27-5.22(\mathrm{~m}, 1 \mathrm{H}), 4.94(\mathrm{~s}, 2 \mathrm{H})$, 4.11-3.93 (m, 2H), 3.80-3.61 (m, 2H), 2.82-2.51 (m, 4H), $2.36(\mathrm{~s}, 3 \mathrm{H}), 2.19-2.08(\mathrm{~m}, 2 \mathrm{H})$, $1.77-1.58(\mathrm{~m}, 8 \mathrm{H}) .{ }^{13} \mathrm{C}$ NMR $\left(101 \mathrm{MHz}, \mathrm{CDCl}_{3}\right) \delta 155.82,155.79,151.67,151.59,150.93,150.90$, $137.47,134.26,129.13,127.33,101.64,101.59,100.66,100.57,96.84,96.75,96.70,93.19,69.88$, $63.08,62.93,62.86,62.57,31.29,31.26,31.14,24.62,24.50,24.32,24.21,23.61,23.45,23.38,23.24$, 22.96, 22.75, 22.61, 21.15. EI-MS $\mathrm{m} / \mathrm{z} 422$ (M). EI-HR-MS $\mathrm{m} / \mathrm{z}$ found: 422.2086; calcd. for $\mathrm{C}_{26} \mathrm{H}_{30} \mathrm{O}_{5}: 422.2088$.

\subsubsection{Compound 19}

The title compound was obtained as a colorless crystal in $66 \%$ yield as a diastereoisomeric mixture of $( \pm)$-19a and $( \pm)-19 b(\sim 1: 1) .{ }^{1} \mathrm{H}$ NMR $\left(400 \mathrm{MHz}, \mathrm{CDCl}_{3}\right) \delta 7.64(\mathrm{~d}, J=8.1 \mathrm{~Hz}, 2 \mathrm{H}), 7.52(\mathrm{~d}$, $J=8.0 \mathrm{~Hz}, 2 \mathrm{H}), 6.10(\mathrm{~s}, 1 \mathrm{H}), 5.31(\mathrm{t}, J=2.9 \mathrm{~Hz}, 1 \mathrm{H}), 5.24(\mathrm{t}, J=3.3 \mathrm{~Hz}, 1 \mathrm{H}), 5.05(\mathrm{~s}, 2 \mathrm{H}), 4.09-3.93$ $(\mathrm{m}, 2 \mathrm{H}), 3.77-3.64(\mathrm{~m}, 2 \mathrm{H}), 2.80-2.58(\mathrm{~m}, 4 \mathrm{H}), 2.23-2.07(\mathrm{~m}, 2 \mathrm{H}), 1.75-1.60(\mathrm{~m}, 8 \mathrm{H})$. ${ }^{13} \mathrm{C}$ NMR $\left(101 \mathrm{MHz}, \mathrm{CDCl}_{3}\right) \delta 155.32,151.73,151.65,151.10,141.37,127.12,125.47,125.44$, $101.58,101.54,101.16,101.08,96.85,96.78,96.74,93.12,69.03,63.19,63.04,62.91,62.63,31.18$, $31.12,29.67,24.64,24.53,24.35,24.25,23.55,23.37,23.29,23.21,22.66$. EI-MS $\mathrm{m} / z 476$ (M). EI-HR-MS $m / z$ found: 476.1809 ; calcd. for $\mathrm{C}_{26} \mathrm{H}_{27} \mathrm{O}_{5} \mathrm{~F}_{3}: 476.1805$.

\subsubsection{Compound 20}

The title compound was obtained as a colorless crystal in $71 \%$ yield as a diastereoisomeric mixture of $( \pm)-20 \mathrm{a}$ and $( \pm)$-20b $(\sim 1: 1) .{ }^{1} \mathrm{H}$ NMR $\left(400 \mathrm{MHz}, \mathrm{CDCl}_{3}\right) \delta 7.40(\mathrm{~s}, 1 \mathrm{H}), 7.32-7.26(\mathrm{~m}, 3 \mathrm{H})$, $6.10(\mathrm{~s}, 1 \mathrm{H}), 5.31(\mathrm{t}, J=2.9 \mathrm{~Hz}, 1 \mathrm{H}), 5.28-5.20(\mathrm{~m}, 1 \mathrm{H}), 4.96(\mathrm{~s}, 2 \mathrm{H}), 4.06-3.94(\mathrm{~m}, 2 \mathrm{H})$, 3.80-3.63 (m, 2H), 2.84-2.52 (m, 4H), 2.24-2.08 (m, 2H), 1.80-1.59 (m, 8H). ${ }^{13} \mathrm{C}$ NMR (101 MHz, 
$\left.\mathrm{CDCl}_{3}\right) \delta 155.36,155.33,151.62,151.54,151.01,150.98,139.33,134.40,129.77,127.89,127.09$, $125.08,101.57,101.51,100.99,100.90,96.81,96.75,96.69,93.06,69.02,63.18,63.02,62.86,62.56$, 31.17, 31.13, 31.07, 31.04, 24.60, 24.47, 24.25, 24.14, 23.59, 23.43, 23.37, 23.28, 22.96, 22.66, 22.51. EI-MS $m / z 442$ (M). EI-HR-MS $m / z$ found: 442.1545; calcd. for $\mathrm{C}_{25} \mathrm{H}_{27} \mathrm{O}_{5} \mathrm{Cl}_{1}: 442.1542$.

\subsection{Typical Method to Prepare 21-23, Using 21 as an Example}

\subsubsection{Compound 21}

A solution of compound $7(0.1 \mathrm{~g}, 0.27 \mathrm{mmol})$ and ammonia $(5 \mathrm{~mL})$ in acetone $(10 \mathrm{~mL})$ was stirred in a sealed tube at $60{ }^{\circ} \mathrm{C}$ for $5 \mathrm{~h}$ and monitored via thin layer chromatography. The resultant mixture was then poured into water $(50 \mathrm{~mL})$ and extracted with ethyl acetate $(3 \times 30 \mathrm{~mL})$. The combined organic layers were washed with saturated brine $(50 \mathrm{~mL})$, dried over anhydrous magnesium sulfate and concentrated in vacuo. Purification via flash chromatography using petroleum ethyl acetate: ether (3:2) as the eluant afforded the title compound $(80 \mathrm{mg}, 0.22 \mathrm{mmol}, 82 \%)$ as a colorless crystal consisting of a diastereoisomeric mixture of $( \pm)-21 \mathrm{a}$ and $( \pm)-21 \mathbf{b}(\sim 1: 1) .{ }^{1} \mathrm{H}$ NMR $\left(400 \mathrm{MHz}, \mathrm{CDCl}_{3}\right)$ $\delta 14.11(\mathrm{~s}, 1 \mathrm{H}), 14.11(\mathrm{~s}, 1 \mathrm{H}), 8.17(\mathrm{~s}, 2 \mathrm{H}), 5.71(\mathrm{~s}, 2 \mathrm{H}), 5.54-5.38(\mathrm{~m}, 2 \mathrm{H}), 5.38-5.17(\mathrm{~m}, 2 \mathrm{H})$, 4.09-3.85 (m, 4H), 3.85-3.63 (m, 4H), 2.85-2.51 (m, 8H), 2.29-2.08 (m, 4H), 1.80-1.54 (m, 16H). ${ }^{13} \mathrm{C}$ NMR $\left(101 \mathrm{MHz}, \mathrm{CDCl}_{3}\right) \delta 172.74,161.84,161.80,155.03,154.96,151.21,151.11,101.30$, $101.21,98.21,98.12,97.64,97.36,97.29,96.00,62.82,62.42,62.35,62.24,31.02,30.94,30.82$, $30.74,24.09,23.97,23.90,23.64,23.51,23.45,22.87,22.51$. EI-MS $m / z 361$ (M). EI-HR-MS $\mathrm{m} / z$ found: 361.1520 ; calcd. for $\mathrm{C}_{19} \mathrm{H}_{23} \mathrm{O}_{6} \mathrm{~N}_{1}: 361.1520$.

\subsubsection{Compound 22}

The title compound was obtained with compound 7 similar to the method for synthesizing compound 21 by replacing ammonia with methylamine as a colorless crystal in $90 \%$ yield as a diastereoisomeric mixture of $( \pm)-22 \mathbf{a}$ and $( \pm)$-22b $(\sim 1: 1) .{ }^{1} \mathrm{H}$ NMR $\left(400 \mathrm{MHz}, \mathrm{CDCl}_{3}\right) \delta 14.39(\mathrm{~s}, 1 \mathrm{H})$, $14.38(\mathrm{~s}, 1 \mathrm{H}), 8.33(\mathrm{~s}, 2 \mathrm{H}), 5.47-5.38(\mathrm{~m}, 2 \mathrm{H}), 5.38-5.26(\mathrm{~m}, 2 \mathrm{H}), 4.04-3.87(\mathrm{~m}, 4 \mathrm{H})$, 3.84-3.64 (m, 4H), $2.97(\mathrm{~s}, 3 \mathrm{H}), 2.95(\mathrm{~s}, 3 \mathrm{H}), 2.85-2.51(\mathrm{~m}, 8 \mathrm{H}), 2.23-2.09(\mathrm{~m}, 4 \mathrm{H})$, $1.76-1.59(\mathrm{~m}, 16 \mathrm{H}) .{ }^{13} \mathrm{C} \mathrm{NMR}\left(101 \mathrm{MHz}, \mathrm{CDCl}_{3}\right) \delta 171.22,161.26,161.22,154.18,154.12,150.70$, 150.60, 101.40, 101.31, 98.01, 97.92, 97.60, 97.29, 97.22, 96.64, 62.85, 62.59, 62.47, 60.33, 31.07, $30.99,30.79,30.71,26.03,24.14,23.97,23.80,23.73,23.63,23.60,23.43,23.30,23.25,22.89,22.54$, 14.16. EI-MS $m / z 375$ (M). EI-HR-MS $m / z$ found: 375.1666 ; calcd. for $\mathrm{C}_{20} \mathrm{H}_{25} \mathrm{O}_{6} \mathrm{~N}_{1}: 375.1676$.

\subsubsection{Compound 23}

The title compound was obtained with compound 7 similar to the method for synthesizing compound 21 by replacing ammonia with butylamine as a colorless crystal in $81 \%$ yield as a diastereoisomeric mixture of $( \pm)-23 \mathbf{a}$ and $( \pm)$-23b $(\sim 1: 1) .{ }^{1} \mathrm{H}$ NMR $\left(400 \mathrm{MHz}, \mathrm{CDCl}_{3}\right) \delta 14.43(\mathrm{~s}, 1 \mathrm{H})$, $8.43(\mathrm{~s}, 1 \mathrm{H}), 5.44-5.38(\mathrm{~m}, 1 \mathrm{H}), 5.34-5.27(\mathrm{~m}, 1 \mathrm{H}), 4.04-3.85(\mathrm{~m}, 2 \mathrm{H}), 3.84-3.63(\mathrm{~m}, 2 \mathrm{H})$, 3.51-3.27 (m, 2H), 2.90-2.47 (m, 4H), 2.31-2.07 (m, 2H), 1.77-1.51 (m, 10H), 1.49-1.38 (m, 2H), $0.95(\mathrm{t}, J=7.3 \mathrm{~Hz}, 3 \mathrm{H}) .{ }^{13} \mathrm{C}$ NMR $\left(101 \mathrm{MHz}, \mathrm{CDCl}_{3}\right) \delta 170.43,161.33,161.29,154.16,154.09$, 150.86, 150.77, 101.36, 101.26, 97.87, 97.78, 97.57, 97.27, 97.20, 96.63, 96.61, 62.84, 62.43, 61.99, 
$61.91,39.36,38.88,31.34,31.24,31.08,30.98,30.89,30.80,24.13,23.94,23.78,23.64,23.50,23.42$, 23.37, 22.91, 22.52, 20.15, 19.94, 13.67, 13.57. EI-MS $m / z 417$ (M). EI-HR-MS $m / z$ found: 417.2141; calcd. for $\mathrm{C}_{23} \mathrm{H}_{31} \mathrm{O}_{6} \mathrm{~N}_{1}$ : 417.2146 .

\subsection{Typical Method to Prepare 24-39, Using $\mathbf{2 4}$ as an Example}

\subsubsection{Compound 24}

To a solution of compound $6(0.1 \mathrm{~g}, 0.28 \mathrm{mmol})$, Ala-OMe.HCl $(70 \mathrm{mg}, 0.56 \mathrm{mmol})$ and BOP $(0.18 \mathrm{~g}, 0.42 \mathrm{mmol})$ in dichloromethane $(5 \mathrm{~mL})$ was added DIEA $(0.5 \mathrm{~g}, 3.9 \mathrm{mmol})$. This solution was stirred at room temperature and monitored by thin layer chromatography. The resultant mixture was then diluted with $100 \mathrm{~mL}$ of ethyl acetate and washed with $1 \mathrm{M} \mathrm{HCl}(50 \mathrm{~mL})$ and saturated brine $(50 \mathrm{~mL})$ before drying over anhydrous magnesium sulfate and concentrating in vacuo. Purification by flash chromatography using ethyl acetate:petroleum ether $(1: 10)$ as the eluant afforded the title compound ( $0.11 \mathrm{~g}, 0.25 \mathrm{mmol}, 90 \%$ yield) as a colorless crystal consisting of a diastereoisomeric mixture of $( \pm)$-24a and $( \pm)$-24b $(\sim 1: 1) .{ }^{1} \mathrm{H}$ NMR $\left(400 \mathrm{MHz}, \mathrm{CDCl}_{3}\right) \delta 14.06(\mathrm{~s}, 1 \mathrm{H}), 9.01(\mathrm{~s}, 1 \mathrm{H})$, 5.53-5.42 (m, 1H), 5.38-5.28 (m, 1H), 4.89-4.62 (m, 1H), 4.14-4.03 (m, 1H), 4.02-3.90 (m, 1H), $3.88-3.80(\mathrm{~m}, 1 \mathrm{H}), 3.78(\mathrm{~s}, 3 \mathrm{H}), 3.75-3.66(\mathrm{~m}, 1 \mathrm{H}), 2.80-2.58(\mathrm{~m}, 4 \mathrm{H}), 2.25-2.12(\mathrm{~m}, 2 \mathrm{H})$, $1.84-1.56(\mathrm{~m}, 8 \mathrm{H}), 1.51(\mathrm{~d}, J=7.1 \mathrm{~Hz}, 3 \mathrm{H}) .{ }^{13} \mathrm{C} \mathrm{NMR}\left(101 \mathrm{MHz}, \mathrm{CDCl}_{3}\right) \delta 173.34,169.88,161.34$, 154.61, 151.22, 101.08, 97.98, 97.70, 97.17, 96.21, 62.39, 61.74, 52.42, 48.14, 30.97, 30.84, 29.68, 24.29, 24.07, 23.83, 23.64, 23.17, 22.90, 18.53. EI-MS $m / z 447$ (M). EI-HR-MS $m / z$ found: 447.1886; calcd. for $\mathrm{C}_{23} \mathrm{H}_{29} \mathrm{O}_{8} \mathrm{~N}_{1}$ : 447.1888 .

\subsubsection{Compound 25}

The title compound was obtained as a colorless crystal in 54\% yield as a diastereoisomeric mixture of ( \pm )-25a and $( \pm)-25 \mathbf{b}(\sim 1: 1) .{ }^{1} \mathrm{H}$ NMR $\left(400 \mathrm{MHz}, \mathrm{CDCl}_{3}\right) \delta 12.93(\mathrm{~s}, 1 \mathrm{H}), 5.44$ (dd, $J=6.0,2.5 \mathrm{~Hz}$, $1 \mathrm{H}), 5.34(\mathrm{dd}, J=5.1,2.7 \mathrm{~Hz}, 1 \mathrm{H}), 4.21-3.88(\mathrm{~m}, 2 \mathrm{H}), 3.84-3.68(\mathrm{~m}, 2 \mathrm{H}), 2.94(\mathrm{t}, J=7.3 \mathrm{~Hz}, 2 \mathrm{H})$, 2.76-2.50 (m, 4H), 2.24-2.10 (m, 2H), 1.72-1.59 (m, 8H), 1.56-1.30 (m, 4H), 0.94 (t, J=7.3 Hz, 3H). EI-MS $m / z 434$ (M). EI-HR-MS $m / z$ found: 434.1759; calcd. for $\mathrm{C}_{23} \mathrm{H}_{30} \mathrm{O}_{6} \mathrm{~S}_{1}: 434.1758$.

\subsubsection{Compound 26}

The title compound was obtained as a light yellow crystal in $98 \%$ yield as a diastereoisomeric mixture of $( \pm)$-26a and $( \pm)$-26b $(\sim 1: 1) .{ }^{1} \mathrm{H}$ NMR $\left(400 \mathrm{MHz}, \mathrm{CDCl}_{3}\right) \delta 14.36(\mathrm{~s}, 1 \mathrm{H}), 8.53(\mathrm{~s}, 1 \mathrm{H})$, $7.14(\mathrm{dd}, J=5.1,1.2 \mathrm{~Hz}, 1 \mathrm{H}), 6.92(\mathrm{dd}, J=5.1,3.4 \mathrm{~Hz}, 1 \mathrm{H}), 6.88$ (dd, $J=3.4,0.9 \mathrm{~Hz}, 1 \mathrm{H})$, 5.38-5.27 (m, 2H), 4.03-3.90 (m, 1H), $3.81(\mathrm{~m}, 1 \mathrm{H}), 3.76-3.56(\mathrm{~m}, 4 \mathrm{H}), 3.30-3.01(\mathrm{~m}, 2 \mathrm{H})$, 2.83-2.51 (m, 4H), 2.24-2.08 (m, 2H), 1.85-1.57 (m, 8H). ${ }^{13} \mathrm{C}$ NMR (101 MHz, $\left.\mathrm{CDCl}_{3}\right) \delta 170.59$, $161.31,154.27,154.18,150.74,150.64,141.46,126.87,125.31,123.75,101.30,101.20,98.03,97.93$, $97.47,97.22,97.14,96.43,62.42,62.34,62.20,40.70,30.95,30.86,30.65,30.57,29.76,29.65,24.06$, 23.85, 23.76, 23.59, 23.44, 23.32, 22.87, 22.46. EI-MS $m / z 471$ (M). EI-HR-MS $m / z$ found: 471.1712; calcd. for $\mathrm{C}_{25} \mathrm{H}_{29} \mathrm{O}_{6} \mathrm{~N}_{1} \mathrm{~S}_{1}: 471.1710$. 


\subsubsection{Compound 27}

The title compound was obtained as a light yellow crystal in $70 \%$ yield as a diastereoisomeric mixture of $( \pm)-27 \mathbf{a}$ and $( \pm)-27 \mathbf{b}(\sim 1: 1) .{ }^{1} \mathrm{H}$ NMR $\left(400 \mathrm{MHz}, \mathrm{CDCl}_{3}\right) \delta 14.12(\mathrm{~s}, 1 \mathrm{H}), 8.73(\mathrm{~s}, 1 \mathrm{H})$, $7.31-7.19(\mathrm{~m}, 4 \mathrm{H}), 5.36(\mathrm{~s}, 1 \mathrm{H}), 5.30(\mathrm{~s}, 1 \mathrm{H}), 4.63(\mathrm{dd}, J=15.2,5.9 \mathrm{~Hz}, 1 \mathrm{H}), 4.48(\mathrm{dd}, J=15.1$, $4.8 \mathrm{~Hz}, 1 \mathrm{H}), 4.00-3.85(\mathrm{~m}, 1 \mathrm{H}), 3.75-3.56(\mathrm{~m}, 3 \mathrm{H}), 2.79-2.50(\mathrm{~m}, 4 \mathrm{H}), 2.21-2.05(\mathrm{~m}, 2 \mathrm{H}), 1.76-1.53$ $(\mathrm{m}, 8 \mathrm{H}) .{ }^{13} \mathrm{C} \mathrm{NMR}\left(101 \mathrm{MHz}, \mathrm{CDCl}_{3}\right) \delta 170.52,161.40,154.62,154.54,154.49,150.90,150.81$, $136.89,133.13,128.85,128.78,101.49,101.39,98.15,98.07,97.66,97.34,97.27,96.43,62.85,62.48$, 62.16, 62.07, 42.58, 31.05, 30.97, 30.81, 30.73, 24.13, 23.98, 23.64, 23.59, 23.43, 22.91, 22.57. EI-MS $m / z 485$ (M). EI-HR-MS $m / z$ found: 485.1606; calcd. for $\mathrm{C}_{26} \mathrm{H}_{28} \mathrm{O}_{6} \mathrm{~N}_{1} \mathrm{Cl}_{1}$ : 485.1600 .

\subsubsection{Compound 28}

The title compound was obtained as a colorless crystal in $100 \%$ yield as a diastereoisomeric mixture of $( \pm)$-28a and $( \pm)$-28b $(\sim 1: 1) .{ }^{1} \mathrm{H}$ NMR $\left(400 \mathrm{MHz}, \mathrm{CDCl}_{3}\right) \delta 14.59(\mathrm{~s}, 1 \mathrm{H}), 8.41(\mathrm{~s}, 1 \mathrm{H})$, 5.44-5.37 (m, 1H), 5.37-5.27 (m, 1H), 4.00-3.88 (m, 2H), 3.83-3.75 (m, 1H), 3.75-3.65 (m, 1H), 2.82-2.53 (m, 4H), 2.23-2.14 (m, 2H), 2.14-2.07 (m, 9H), 1.80-1.69 (m, 8H), 1.68-1.57 (m, 6H). ${ }^{13} \mathrm{C}$ NMR $\left(101 \mathrm{MHz}, \mathrm{CDCl}_{3}\right) \delta 169.93,161.59,161.54,153.84,153.76,150.68,150.59,101.41$, $101.29,97.56,97.26,97.15,62.85,62.37,61.69,52.21,41.69,36.47,31.13,31.01,30.97,30.86$, $29.68,29.51,24.37,24.21,24.13,23.90,23.72,23.45,23.30,23.17,23.01,22.56,14.18$. EI-MS $m / z 495$ (M). EI-HR-MS $m / z$ found: 495.2612; calcd. for $\mathrm{C}_{29} \mathrm{H}_{37} \mathrm{O}_{6} \mathrm{~N}_{1}$ : 495.2615.

\subsubsection{Compound 29}

The title compound was obtained as a colorless crystal in $42 \%$ yield as a diastereoisomeric mixture of $( \pm)$-29a and $( \pm)-29 b(\sim 1: 1) .{ }^{1} \mathrm{H}$ NMR $\left(300 \mathrm{MHz}, \mathrm{CDCl}_{3}\right) \delta 13.89(\mathrm{~s}, 1 \mathrm{H}), 10.60(\mathrm{~s}, 1 \mathrm{H})$, $8.17(\mathrm{~s}, 1 \mathrm{H}), 7.68(\mathrm{~d}, J=8.0 \mathrm{~Hz}, 1 \mathrm{H}), 7.60(\mathrm{~d}, J=7.7 \mathrm{~Hz}, 1 \mathrm{H}), 7.44(\mathrm{t}, J=7.8 \mathrm{~Hz}, 1 \mathrm{H})$, $5.54(\mathrm{t}, J=3.2 \mathrm{~Hz}, 1 \mathrm{H}), 5.45-5.33(\mathrm{~m}, 1 \mathrm{H}), 4.05-3.73(\mathrm{~m}, 4 \mathrm{H}), 2.69-2.63(\mathrm{~m}, 4 \mathrm{H}), 2.34-2.14(\mathrm{~m}, 2 \mathrm{H})$, $1.75-1.60(\mathrm{~m}, 8 \mathrm{H})$. EI-MS $m / z 480(\mathrm{M})$.

\subsubsection{Compound $\mathbf{3 0}$}

The title compound was obtained as a colorless crystal in $71 \%$ yield as a diastereoisomeric mixture of ( \pm -30a and $( \pm)$-30b $(\sim 1: 1) .{ }^{1} \mathrm{H}$ NMR $\left(400 \mathrm{MHz}, \mathrm{CDCl}_{3}\right) \delta 14.42(\mathrm{~s}, 1 \mathrm{H}), 8.41(\mathrm{~s}, 1 \mathrm{H})$, $7.09(\mathrm{~d}, J=8.4 \mathrm{~Hz}, 2 \mathrm{H}), 6.75(\mathrm{~d}, J=8.5 \mathrm{~Hz}, 1 \mathrm{H}), 5.35-5.30(\mathrm{~m}, 1 \mathrm{H}), 5.30-5.25(\mathrm{~m}, 1 \mathrm{H}), 4.13-3.85$ $(\mathrm{m}, 2 \mathrm{H}), 3.78-3.58(\mathrm{~m}, 4 \mathrm{H}), 2.90-2.77(\mathrm{~m}, 2 \mathrm{H}), 2.74-2.58(\mathrm{~m}, 4 \mathrm{H}), 2.19-2.11(\mathrm{~m}, 2 \mathrm{H})$, 1.74-1.62 (m, 8H). ${ }^{13} \mathrm{C}$ NMR (101 MHz, $\left.\mathrm{CDCl}_{3}\right) \delta 170.54,161.34,161.29,154.33,154.15,150.77$, $150.66,131.05,129.91,115.37,101.36,98.06,97.50,97.27,97.20,97.07,97.01,96.56,62.92,62.35$, 40.76, 34.55, 31.03, 30.94, 30.71, 30.65, 29.68, 26.90, 24.13, 23.91, 23.64, 23.49, 23.38, 23.27, 22.90, 22.63, 22.48. EI-MS $m / z 481$ (M). EI-HR-MS $m / z$ found: 481.2087; calcd. for $\mathrm{C}_{27} \mathrm{H}_{31} \mathrm{O}_{7} \mathrm{~N}_{1}: 481.2095$. 


\subsubsection{Compound 31}

The title compound was obtained as a colorless crystal in $51 \%$ yield as a diastereoisomeric mixture of ( \pm )-31a and $( \pm)-31 \mathrm{~b}(\sim 1: 1) .{ }^{1} \mathrm{H}$ NMR $\left(400 \mathrm{MHz}, \mathrm{CDCl}_{3}\right) \delta 14.02(\mathrm{~s}, 1 \mathrm{H}), 8.87(\mathrm{~s}, 1 \mathrm{H}), 5.46(\mathrm{~s}, 1 \mathrm{H})$, $5.34(\mathrm{~s}, 1 \mathrm{H}), 4.93-4.62(\mathrm{~m}, 1 \mathrm{H}), 4.12-3.89(\mathrm{~m}, 2 \mathrm{H}), 3.90-3.39(\mathrm{~m}, 5 \mathrm{H}), 2.87-2.49(\mathrm{~m}, 4 \mathrm{H})$, 2.28-2.07 (m, 2H), 1.85-1.45 (m, 12H), $0.97(\mathrm{~d}, J=5.6 \mathrm{~Hz}, 6 \mathrm{H}) .{ }^{13} \mathrm{C}$ NMR $(101 \mathrm{MHz}, \mathrm{CDCl} 3)$ $\delta 173.31,170.16,161.39,154.64,154.59,151.26,151.17,101.27,101.17,98.05,97.97,97.76,97.30$, $97.22,96.29,62.79,62.40,61.61,52.17,50.81,41.61,31.03,30.93,25.03,24.40,24.25,24.17,24.05$, 23.90, 23.67, 23.46, 23.28, 23.16, 22.93, 22.79, 22.57, 22.08. EI-MS $m / z \quad 489$ (M). EI-HR-MS $m / z$ found: 489.2351 ; calcd. for $\mathrm{C}_{26} \mathrm{H}_{35} \mathrm{O}_{8} \mathrm{~N}_{1}: 489.2357$.

\subsubsection{Compound 32}

The title compound was obtained as a light yellow crystal in $80 \%$ yield as a diastereoisomeric mixture of $( \pm)$-32a and $( \pm)-32 \mathbf{b}(\sim 1: 1) .{ }^{1} \mathrm{H}$ NMR $\left(400 \mathrm{MHz}, \mathrm{CDCl}_{3}\right) \delta 13.97-13.74(\mathrm{~m}, 1 \mathrm{H})$, 9.28-9.06 (m, 1H), 5.51-5.40 (m, 1H), 5.40-5.28 (m, 1H), 5.11-4.91 (m, 1H), 4.13-3.88 (m, 2H), 3.82-3.59 (m, 5H), 3.51-3.04 (m, 2H), 2.84-2.47 (m, 4H), 2.27-2.09 (m, 2H), 1.77-1.54 (m, 8H). EI-MS $m / z 479$ (M). EI-HR-MS $m / z$ found: 479.1605; calcd. for $\mathrm{C}_{23} \mathrm{H}_{29} \mathrm{O}_{8} \mathrm{~N}_{1} \mathrm{~S}_{1}: 479.1608$.

\subsubsection{Compound $\mathbf{3 3}$}

The title compound was obtained as a light yellow crystal in $69 \%$ yield as a diastereoisomeric mixture of $( \pm)$-33a and $( \pm)$-33b $(\sim 1: 1) .{ }^{1} \mathrm{H}$ NMR (400 MHz, $\left.\mathrm{CDCl}_{3}\right) \delta 14.00(\mathrm{~s}, 1 \mathrm{H}), 10.45(\mathrm{~s}, 1 \mathrm{H})$, $7.67-7.45(\mathrm{~m}, 2 \mathrm{H}), 7.13-6.94(\mathrm{~m}, 2 \mathrm{H}), 5.51(\mathrm{~d}, J=2.6 \mathrm{~Hz}, 1 \mathrm{H}), 5.34(\mathrm{~d}, J=2.6 \mathrm{~Hz}, 1 \mathrm{H})$, 4.10-3.61 (m, 4H), 2.92-2.49 (m, 4H), 2.33-2.11 (m, 2H), 1.89-1.56 (m, 8H). ${ }^{13} \mathrm{C}$ NMR (101 MHz, $\left.\mathrm{CDCl}_{3}\right) \delta 168.80,161.71,160.63,158.21,154.78,150.48,133.82,122.58,122.50,115.71,115.49$, 101.74, 98.33, 97.97, 97.35, 96.55, 62.93, 62.09, 30.82, 24.09, 23.88, 23.38, 23.33, 22.42. EI-MS $m / z 455$ (M). EI-HR-MS $m / z$ Found: 455.1741; calcd. for $\mathrm{C}_{25} \mathrm{H}_{26} \mathrm{O}_{6} \mathrm{~N}_{1} \mathrm{~F}_{1}$ : 455.1739.

\subsubsection{Compound 34}

The title compound was obtained as a light yellow crystal in $72 \%$ yield as a diastereoisomeric mixture of $( \pm)$-34a and $( \pm)$-34b $(\sim 1: 1) .{ }^{1} \mathrm{H}$ NMR $\left(400 \mathrm{MHz}, \mathrm{CDCl}_{3}\right) \delta 13.94(\mathrm{~s}, 1 \mathrm{H}), 10.52(\mathrm{~s}, 1 \mathrm{H})$, $7.55(\mathrm{~d}, J=8.8 \mathrm{~Hz}, 2 \mathrm{H}), 7.30(\mathrm{~d}, J=8.8 \mathrm{~Hz}, 2 \mathrm{H}), 5.58-5.47(\mathrm{~m}, 1 \mathrm{H}), 5.39-5.30(\mathrm{~m}, 1 \mathrm{H})$, 4.06-3.62 (m, 4H), 2.84-2.56 (m, 4H), 2.31-2.12 (m, 2H), 1.90-1.53 (m, 8H). ${ }^{13} \mathrm{C}$ NMR (101 MHz, $\mathrm{CDCl} 3) \delta 168.88,161.82,161.77,154.99,154.91,150.57,150.48,136.48,129.24,129.00,128.86$, $122.22,121.96,101.79,101.68,98.39,98.30,98.03,97.38,97.31,96.83,96.75,96.60,62.95,62.50$, $62.09,62.01,60.36,30.95,30.84,30.73,24.12,23.93,23.59,23.37,23.24,22.85,22.43,14.16$. EI-MS $m / z 471$ (M). EI-HR-MS $m / z$ found: 471.1441; calcd. for $\mathrm{C}_{25} \mathrm{H}_{26} \mathrm{O}_{6} \mathrm{~N}_{1} \mathrm{Cl}_{1}$ : 471.1443.

\subsubsection{Compound 35}

The title compound was obtained as a colorless crystal in $64 \%$ yield as a diastereoisomeric mixture of $( \pm)$-35a and $( \pm)$-35b $(\sim 1: 1) .{ }^{1} \mathrm{H}$ NMR $\left(400 \mathrm{MHz}, \mathrm{CDCl}_{3}\right) \delta 14.11(\mathrm{~s}, 1 \mathrm{H}), 8.77(\mathrm{~s}, 1 \mathrm{H}), 5.46-5.38$ 
(m, 1H), 5.39-5.30 (m, 1H), 4.02-3.89 (m, 2H), 3.86-3.80 (m, 2H), 3.79-3.50 (m, 4H), 2.78-2.55 $(\mathrm{m}, 4 \mathrm{H}), 2.45(\mathrm{~s}, 1 \mathrm{H}), 2.25-2.11(\mathrm{~m}, 2 \mathrm{H}), 1.81-1.60(\mathrm{~m}, 8 \mathrm{H}) .{ }^{13} \mathrm{C} \mathrm{NMR}\left(101 \mathrm{MHz}, \mathrm{CDCl}_{3}\right) \delta 171.48$, $161.28,154.49,150.92,150.82,101.45,98.20,97.69,97.34,97.27,96.47,62.85,62.56,62.46,62.36$, $62.26,42.20,31.07,30.99,30.84,30.76,24.12,23.95,23.88,23.61,23.53,23.47,22.57,14.18$. EI-MS $\mathrm{m} / \mathrm{z} 405$ (M). EI-HR-MS m/z found: 405.1780; calcd. for $\mathrm{C}_{21} \mathrm{H}_{27} \mathrm{O}_{7} \mathrm{~N}_{1}: 405.1782$.

\subsubsection{Compound 36}

The title compound was obtained as a colorless crystal in $77 \%$ yield as a diastereoisomeric mixture of $( \pm)$-36a and $( \pm)$-36b $(\sim 1: 1) .{ }^{1} \mathrm{H}$ NMR $\left(400 \mathrm{MHz} \mathrm{CDCl}_{3}\right) \delta$ 7.25-7.11 (m, 5H), 5.41-5.06 (m, 2H), 4.05-3.85 (m, 2H), $3.72(\mathrm{~s}, 2 \mathrm{H}), 3.71-3.53(\mathrm{~m}, 2 \mathrm{H}), 2.91-2.75(\mathrm{~m}, 1 \mathrm{H}), 2.75-2.42(\mathrm{~m}, 4 \mathrm{H})$, 2.25-2.00 (m, 2H), 1.81-1.33 (m, 8H), 1.04 (d, $J=6.3 \mathrm{~Hz}, 6 \mathrm{H})$. EI-MS m/z 493 (M). EI-HR-MS $m / z$ found: 493.2453; calcd. for $\mathrm{C}_{29} \mathrm{H}_{35} \mathrm{O}_{6} \mathrm{~N}_{1}$ : 493.2459 .

\subsubsection{Compound 37}

The title compound was obtained as a colorless crystal in $60 \%$ yield as a diastereoisomeric mixture of $( \pm)-37 \mathbf{a}$ and $( \pm)-37 \mathbf{b}(\sim 1: 1) .{ }^{1} \mathrm{H}$ NMR $\left(400 \mathrm{MHz}, \mathrm{CDCl}_{3}\right) \delta 14.43(\mathrm{~s}, 1 \mathrm{H}), 5.42-5.33(\mathrm{~m}, 1 \mathrm{H})$, 5.32-5.25 (m, 1H), 4.04-3.85 (m, 2H), 3.79-3.64 (m, 2H), 3.57-3.27 (m, 2H), 2.77-2.42 (m, 6H), $2.24(\mathrm{~s}, 6 \mathrm{H}), 2.17-2.07(\mathrm{~m}, 2 \mathrm{H}), 1.70-1.52(\mathrm{~m}, 8 \mathrm{H}) .{ }^{13} \mathrm{C} \mathrm{NMR}\left(101 \mathrm{MHz}, \mathrm{CDCl}_{3}\right) \delta 170.28,161.19$, $161.15,154.09,154.02,153.96,150.95,150.87,150.73,150.65,101.21,101.11,101.05,100.95$, $97.79,97.75,97.71,97.67,97.44,97.13,97.06,96.58,96.45,77.32,77.00,76.68,62.74,62.31,61.93$, $61.86,61.71,61.64,57.47,44.98,39.10,36.91,31.77,30.94,30.89,30.85,30.80,30.75,30.66,29.48$, 29.45, 29.19, 26.94, 24.16, 24.12, 24.02, 23.82, 23.62, 23.53, 23.40, 23.28, 22.78, 22.53, 22.38, 13.96. EI-MS $m / z 432$ (M). EI-HR-MS $m / z$ found: 432.2262; calcd. for $\mathrm{C}_{23} \mathrm{H}_{32} \mathrm{O}_{6} \mathrm{~N}_{2}$ : 432.2255 .

\subsubsection{Compound $\mathbf{3 8}$}

The title compound was obtained as a colorless crystal in $71 \%$ yield as a diastereoisomeric mixture of ( \pm -38a and $( \pm)$-38b $(\sim 1: 1) .{ }^{1} \mathrm{H}$ NMR $\left(400 \mathrm{MHz}, \mathrm{CDCl}_{3}\right) \delta 14.46(\mathrm{~s}, 1 \mathrm{H}), 8.44(\mathrm{~s}, 1 \mathrm{H})$, $5.41(\mathrm{~d}, J=2.6 \mathrm{~Hz}, 1 \mathrm{H}), 5.31(\mathrm{~d}, J=2.5 \mathrm{~Hz}, 1 \mathrm{H}), 4.03-3.85(\mathrm{~m}, 2 \mathrm{H}), 3.84-3.62(\mathrm{~m}, 2 \mathrm{H})$, 3.55-3.22 (m, 2H), 2.91-2.47 (m, 4H), 2.25-2.09 (m, 2H), 1.77-1.54 (m, 10H), 1.40-1.21 (m, 18H), $0.87(\mathrm{t}, J=6.8 \mathrm{~Hz}, 3 \mathrm{H}) .{ }^{13} \mathrm{C}$ NMR $\left(101 \mathrm{MHz}, \mathrm{CDCl}_{3}\right) \delta 170.72,161.59,154.45,154.38,151.16$, $151.07,102.95,101.66,101.56,100.31,98.17,97.87,97.57,97.50,96.93,67.56,63.18,62.84,62.75$, $62.35,62.28,39.65,39.54,35.12,32.20,31.36,31.27,31.18,31.09,29.91,29.88,29.62,28.81,27.37$, 25.67, 24.44, 24.41, 24.30, 24.24, 24.09, 23.80, 23.72, 23.22, 23.13, 22.96, 22.82, 14.38 . EI-MS $m / z 529$ (M). EI-HR-MS $m / z$ found: 529.3404; calcd. for $\mathrm{C}_{31} \mathrm{H}_{47} \mathrm{O}_{6} \mathrm{~N}_{1}: 529.3398$.

\subsubsection{Compound 39}

The title compound was obtained as a colorless crystal in $61 \%$ yield as a diastereoisomeric mixture of $( \pm)$-39a and $( \pm)$-39b $(\sim 1: 1) .{ }^{1} \mathrm{H}$ NMR $\left(400 \mathrm{MHz}, \mathrm{CDCl}_{3}\right) \delta 14.21(\mathrm{~s}, 1 \mathrm{H}), 8.74(\mathrm{~s}, 1 \mathrm{H})$, 5.49-5.38 (m, 1H), 5.38-5.27 (m, 1H), 4.06-3.88 (m, 2H), 3.84-3.64 (m, 3H), 3.62-3.48 (m, 1H), 2.86-2.51 (m, 6H), 2.25-2.11 (m, 2H), $2.04(\mathrm{~s}, 1 \mathrm{H}), 1.82-1.57(\mathrm{~m}, 8 \mathrm{H}) .{ }^{13} \mathrm{C} \mathrm{NMR}\left(101 \mathrm{MHz}, \mathrm{CDCl}_{3}\right)$ 
$\delta 170.70,161.42,161.38,154.51,154.45,150.96,150.87,101.44,101.35,98.16,98.07,97.73,97.33$, $97.27,96.49,62.84,62.45,62.36,42.37,31.07,30.99,30.88,30.80,24.52$, 24.12, 24.02, 23.97, 23.67, 23.60, 23.53, 23.47, 22.92, 22.59. EI-MS $m / z 421$ (M). EI-HR-MS $m / z$ found: 421.1551; calcd. for $\mathrm{C}_{21} \mathrm{H}_{27} \mathrm{O}_{6} \mathrm{~N}_{1} \mathrm{~S}_{1}: 421.1554$.

\subsection{Biological Evaluation}

\subsubsection{Respiratory Burst Assay}

The test compounds, PMA and $\mathrm{H}_{2}$ DCFDA, were prepared as stock solutions in DMSO at concentrations of $200 \mathrm{mM}, 1 \mathrm{mg} / \mathrm{mL}$ and $10 \mathrm{mg} / \mathrm{mL}$, respectively, and stored at $-20{ }^{\circ} \mathrm{C}$ in the dark. The $A B$ strain of zebrafish was used for the respiratory burst assay. These zebrafish were bred and maintained in an Aquatic Habitats system at $\mathrm{pH} 7.6$ with a flow rate of $75 \mathrm{~L} / \mathrm{d}$.

The $A B$ strain of zebrafish was bred to yield embryos. The embryos were collected, rinsed in egg water, transferred to Petri dishes and held at $28{ }^{\circ} \mathrm{C}$ for $72 \mathrm{~h}$ post-fertilization (hpf). ROS production was measured in whole zebrafish embryos at $72 \mathrm{hpf}$. A 96-well microplate was used to measure the respiratory burst, and each well contained one embryo in $100 \mu \mathrm{L}$ of egg water. To each embryo, $100 \mu \mathrm{L}$ of a $100 \mu \mathrm{M}$ solution of test compound in $0.1 \%$ DMSO or $0.1 \%$ DMSO as a control was added. After incubating the plate for $30 \mathrm{~min}$ at $28{ }^{\circ} \mathrm{C}, 50 \mu \mathrm{L}$ of $2 \mu \mathrm{g} / \mathrm{mL} \mathrm{H}_{2}$ DCFDA in $0.2 \% \mathrm{DMSO}$ and $800 \mathrm{ng} / \mathrm{mL}$ PMA in $0.1 \% \mathrm{DMSO}$ were added to each well for a final concentrations of $50 \mu \mathrm{M}$ for each compound, $500 \mathrm{ng} / \mathrm{mL}$ for $\mathrm{H}_{2}$ DCFDA, $0.15 \%$ for DMSO and $200 \mathrm{ng} / \mathrm{mL}$ for PMA. Light was avoided when PMA and $\mathrm{H}_{2}$ DCFDA were used. All solutions were diluted using egg water. The fluorescence was measured using a fluorescence microplate reader at $28{ }^{\circ} \mathrm{C}$ with the excitation and emission filters set to 485 and $530 \mathrm{~nm}$, respectively. The microplates were incubated for $150 \mathrm{~min}$ at $28{ }^{\circ} \mathrm{C}$ without light after adding all solutions, and the fluorescence of each well was measured. The data from six individual embryos per experiment were averaged, and three independent experiments were performed. The fluorescence of the control was treated as $100 \%$, and the measurements of the test compounds are reported relative to the control.

\subsubsection{Worm Strains and Maintenance}

All worm strains were obtained from the Caenorhabditis Genetics Center (CGC, 321 Church Street S.E. Minneapolis, MN, USA). Nematodes were cultured in a standard nematode growth medium (NGM) agar in 60-mm Petri plates and maintained at $20{ }^{\circ} \mathrm{C}$ in a temperature-controlled incubator. Living Escherichia coli bacteria (OP50) provided the food source, and $200 \mu \mathrm{L}$ of bacteria were added to the surface of the NGM plates. The wild-type strain (N2) was used for the longevity-extending assay. The transgenic strain, BZ555 [Pdat-1::GFP], containing the Pdat-1::GFP-linked reporter was used to establish the neuroprotective model and to visualize DA neuron expression.

To obtain age-synchronized worms, plates containing worm-laid eggs were washed with M9 buffer and treated using a standard synchronizing protocol of 2\% sodium hypochlorite and $5 \mathrm{M}$ sodium hydroxide to dissolve the worms. The eggs were then collected via centrifugation, rinsed thrice with M9 buffer, transferred to the surface of the NGM plates and allowed to hatch in the incubator at $20{ }^{\circ} \mathrm{C}$. 


\subsubsection{Longevity-Extending Assay}

The worms that hatched $48 \mathrm{~h}$ after synchronization were transferred to standard NGM plates for pretreatment, and the test compounds were diluted in OP50 and added to the surface at a final concentration of $300 \mu \mathrm{M}$ before incubating overnight at $35^{\circ} \mathrm{C}$. For the control, plates were pretreated with the same amount of DMSO as that used for the drug groups. A total of 30 worms were added to each plate, with 2 plates for each group. After $24 \mathrm{~h}$, the worms were transferred to new plates pretreated with the test compounds and incubated for $24 \mathrm{~h}$. A total of 50 worms from each group were hatched and transferred to standard NGM plates containing juglone in the agar at a final concentration of $500 \mu \mathrm{M}$. Then, the number of dead worms was recorded every hour; each experiment was repeated three times.

\subsubsection{Activities of Anti-Parkinson's Disease with the C. elegans Model}

The synchronized eggs were allowed to hatch overnight at $20{ }^{\circ} \mathrm{C}$ and reach the L1 stage. Neuroprotective activity was investigated using 96-well plates. To each well, $30 \mu \mathrm{L}$ of water containing $10 \%$ OP50 (v/v) and either a test compound, DMSO blank or vehicle control were added. Next, $10 \mu \mathrm{L}$ of water containing $20 \mathrm{~L} 1$ stage worms were added to each well followed by $10 \mu \mathrm{L}$ of $5 \mathrm{mM}$ MPP+ for a total volume of $50 \mu \mathrm{L}$. The final concentration for the test compounds was $100 \mu \mathrm{M}$ in $0.1 \% \mathrm{DMSO}$, with $1 \mathrm{mM}$ of MPP+. The vehicle control contained $10 \mu \mathrm{L}$ of water instead of the $\mathrm{MPP}+$ solution. Approximately $48 \mathrm{~h}$ after exposure to MPP+, worm viability and DA neuron degeneration were observed using a microscope. The survival rate of the DMSO group was considered to be $100 \%$, and the other groups were normalized as the percent of the vehicle control. The desired MPP+ concentration was set by trial and error, such that the survival rate of worms incubated with only MPP + was approximately $50 \%$ of vehicle control. To visualize the DA neurons, the worms were placed on $2 \%$ agarose pads and immobilized with $3 \mathrm{mM}$ levamisole before examining under a fluorescent microscope. The results were obtained from three independent experiments of six replicates each.

\subsubsection{Anti-PD Activity Using a Mouse Model}

Three- to four-month-old male $C 57 B L / 6$ mice weighing 25-27 g each were maintained under a constant $12 \mathrm{~h}$ light-dark cycle and allowed free access to food and water in a room at $23{ }^{\circ} \mathrm{C}$ with a relative humidity of $45 \%-55 \%$. MPTP was diluted in physiological saline, and compounds 1 and $\mathbf{8}$ were diluted in less than $0.3 \%$ DMSO in saline. All of the injection solutions were freshly prepared before use.

The animals were randomly assigned to 6 groups (each containing 6 mice) consisting of the model group, the control group, two groups for compound $1(40 \mathrm{mg} / \mathrm{kg}$ and $10 \mathrm{mg} / \mathrm{kg}$ ) and two groups for compound $8(40 \mathrm{mg} / \mathrm{kg}$ and $10 \mathrm{mg} / \mathrm{kg})$. The model group was injected with a $30 \mathrm{mg} / \mathrm{kg}$ dose of MPTP daily. The first test groups received intraperitoneal injections of the relevant compounds over 5 days, and the model group received saline. The model and compound-treated groups received subcutaneous MPTP injections for 1 day, intraperitoneal injection for 4 days and another subcutaneous injection on the last day. All of the model and compound-treated groups were injected with saline and the pertinent 
compounds, respectively, 1 hour before injecting with MPTP. During the treatment schedule, the control group received a saline injection of the same volume. Approximately $12 \mathrm{~h}$ after the last injection, the mice were transcardially perfused with $200 \mathrm{~mL}$ of a $10 \%$ polyformic solution under anesthesia. The brain tissues were immediately collected and maintained in a $10 \%$ polyformic solution for $12 \mathrm{~h}$. These brain tissues were dehydrated in a $20 \%$ sucrose solution for $24 \mathrm{~h}$ and a $30 \%$ sucrose solution for another $24 \mathrm{~h}$. The brain tissue slices were then prepared. For the immunofluorescent staining, the SN tissue slices were incubated with primary antibodies for SN (mouse anti-tyrosine hydroxylase) overnight at $48{ }^{\circ} \mathrm{C}$ and in daylight 594-conjugated secondary antibodies (goat anti-mouse $\operatorname{Ig} G[H+L]$ secondary antibody). The images were captured using a fluorescent microscope equipped with a digital camera and connected to a computer. The number of DA neurons was counted using Image J software.

\subsubsection{Statistics}

All of the statistics were obtained using SPSS Statistics 18 software. The survival analysis used the Kaplan-Meier method. A one-way analysis of variance (ANOVA) followed by a post hoc test was performed to evaluate the effects of different groups.

\section{Conclusions}

In conclusion, the neuroprotective activity of 39 novel xyloketal derivatives and Xyl-B were evaluated using respiratory burst and longevity-extending assays. The results indicated that many of the derivatives had better activity than Xyl-B. The SAR analysis indicated that the benzopyrano pyran derivatives had excellent antioxidative and neuroprotective activities. Because of the importance of oxidative stress to $\mathrm{PD}$, the neuroprotective activities of 15 selected compounds were investigated using an MPP+-induced C. elegans PD model. Compounds 1 and $\mathbf{8}$ showed the highest neuroprotective activity based on the worm survival rates of $77 \%$ and $81 \%$, respectively, for these compounds. In the mouse PD model, compounds $\mathbf{1}$ and $\mathbf{8}$ further demonstrated notable protective actions. In addition, these compounds were easily synthesized in excellent yield. These exciting results provide a new perspective on the neuroprotective activity of xyloketals.

\section{Acknowledgments}

This work was supported by the National Natural Science Foundation of China (21172271), the National Basic Research Program of China (973 Program, No.2011CB504100), the Natural Science Foundation of Guangdong Province, China (Grant No. S2011020001231), and Fundamental Research Funds for the Central Universities (11lgpy75).

\section{Conflicts of Interest}

The authors declare no conflict of interest 


\section{References}

1. Dauer, W.; Przedborski, S. Parkinson's Disease: Mechanisms and Models. Neuron 2003, 39, 889-909.

2. Henchcliffe, C.; Beal, M.F. Mitochondrial biology and oxidative stress in Parkinson disease pathogenesis. Nat. Clin. Pract. Neuro. 2008, 4, 600-609.

3. Dexter, D.; Carter, C.; Wells, F.; Javoy-Agid, F.; Agid, Y.; Lees, A.; Jenner, P.; Marsden, C. Basal lipid peroxidation in substantia nigra is increased in Parkinson's disease. J. Neurochem. 1989, 52, 381-389.

4. Zhang, J.; Perry, G.; Smith, M.A.; Robertson, D.; Olson, S.J.; Graham, D.G.; Montine, T.J. Parkinson's disease is associated with oxidative damage to cytoplasmic DNA and RNA in substantia nigra neurons. Am. J. Pathol. 1999, 154, 1423-1429.

5. Jenner, P. Oxidative stress in Parkinson's disease. Ann. Neurol. 2003, 53, S26-S38.

6. Cleren, C.; Yang, L.; Lorenzo, B.; Calingasan, N.Y.; Schomer, A.; Sireci, A.; Wille, E.J.; Beal, M.F. Therapeutic effects of coenzyme Q10 (CoQ10) and reduced CoQ10 in the MPTP model of Parkinsonism. J. Neurochem. 2008, 104, 1613-1621.

7. Quinzii, C.M.; López, L.C.; Gilkerson, R.W.; Dorado, B.; Coku, J.; Naini, A.B.; Lagier-Tourenne, C.; Schuelke, M.; Salviati, L.; Carrozzo, R. Reactive oxygen species, oxidative stress, and cell death correlate with level of CoQ10 deficiency. FASEB J. 2010, 24, 3733-3743.

8. Ungerstedt, U. 6-Hydroxy-dopamine induced degeneration of central monoamine neurons. Eur. J. Pharmacol. 1968, 5, 107-110.

9. Langston, J.W.; Ballard, P.; Tetrud, J.W.; Irwin, I. Chronic Parkinsonism in humans due to a product of meperidine-analog synthesis. Science 1983, 219, 979-980.

10. Liou, H.; Tsai, M.; Chen, C.; Jeng, J.; Chang, Y.; Chen, S.; Chen, R. Environmental risk factors and Parkinson's disease. Neurology 1997, 48, 1583-1588.

11. Talpade, D.J.; Greene, J.G.; Higgins, D.S., Jr.; Greenamyre, J.T. In Vivo Labeling of Mitochondrial Complex I (NADH: UbiquinoneOxidoreductase) in Rat Brain Using [3H] Dihydrorotenone. J. Neurochem. 2000, 75, 2611-2621.

12. Seniuk, N.; Tatton, W.; Greenwood, C. Dose-dependent destruction of the coeruleus-cortical and nigral-striatal projections by MPTP. Brain Res. 1990, 527, 7-20.

13. Muthane, U.; Ramsay, K.; Jiang, H.; Jackson-Lewis, V.; Donaldson, D.; Fernando, S.; Ferreira, M.; Przedborski, S. Differences in nigral neuron number and sensitivity to 1-methyl-4-phenyl-1, 2, 3, 6-tetrahydropyridine in C57/bl and CD-1 mice. Exp. Neurol. 1994, 126, 195-204.

14. Ovadia, A.; Zhang, Z.; Gash, D.M. Increased susceptibility to MPTP toxicity in middle-aged rhesus monkeys. Neurobiol. Aging 1995, 16, 931-937.

15. Harrington, A.J.; Hamamichi, S.; Caldwell, G.A.; Caldwell, K.A. C. elegans as a model organism to investigate molecular pathways involved with Parkinson's disease. Dev. Dyn. 2010, 239, 1282-1295.

16. Kampkötter, A.; Gombitang Nkwonkam, C.; Zurawski, R.F.; Timpel, C.; Chovolou, Y.; Wätjen, W.; Kahl, R. Effects of the flavonoids kaempferol and fisetin on thermotolerance, oxidative stress and FoxO transcription factor DAF-16 in the model organism Caenorhabditis elegans. Arch. Toxicol. 2007, 81, 849-858. 
17. Zhang, L.; Jie, G.; Zhang, J.; Zhao, B. Significant longevity-extending effects of EGCG on Caenorhabditis elegans under stress. Free Radical Biol. Med. 2009, 46, 414-421.

18. Li, J.; Baud, O.; Vartanian, T.; Volpe, J.J.; Rosenberg, P.A. Peroxynitrite generated by inducible nitric oxide synthase and NADPH oxidase mediates microglial toxicity to oligodendrocytes. Proc. Natl. Acad. Sci. USA 2005, 102, 9936-9941.

19. Braungart, E.; Gerlach, M.; Riederer, P.; Baumeister, R.; Hoener, M. Caenorhabditis elegans MPP+ model of Parkinson's disease for high-throughput drug screenings. Neurodegener. Dis. 2004, 1, 175-183.

20. Wu, X.; Liu, X.; Jiang, G.; Lin, Y.; Chan, W.; Vrijmoed, L. Xyloketal G, a novel metabolite from the mangrove fungus Xylaria sp. 2508. Chem. Nat. Compd. 2005, 41, 27-29.

21. Lin, Y.; Wu, X.; Feng, S.; Jiang, G.; Luo, J.; Zhou, S.; Vrijmoed, L.L.; Jones, E.B.; Krohn, K.; Steingrover, K.; et al. Five unique compounds: Xyloketals from mangrove fungus Xylaria sp. from the South China Sea coast. J. Org. Chem. 2001, 66, 6252-6256.

22. Wu, X.Y.; Liu, X.H.; Lin, Y.C.; Luo, J.H.; She, Z.G.; Li, H.J.; Chan, W.L.; Antus, S.; Kurtan, T.; Elsasser, B.; et al. Xyloketal F: A strong L-calcium channel blocker from the mangrove fungus Xylaria sp. (\#2508) from the South China Sea coast. Eur. J. Org. Chem. 2005, 4061-4064.

23. Xu, F.; Zhang, Y.; Wang, J.; Pang, J.; Huang, C.; Wu, X.; She, Z.; Vrijmoed, L.L.P.; Jones, E.B.G.; Lin, Y. Benzofuran Derivatives from the Mangrove Endophytic Fungus Xylaria sp. (\#2508). J. Nat. Prod. 2008, 71, 1251-1253.

24. Yin, W.Q.; Lin, Y.C.; She, Z.G.; Vrijmoed, L.L.P.; Jones, E.B.G. A new compound: Xyloketal H from mangrove fungus Xylaria sp. from the South China Sea Coast. Chem. Nat. Compd. 2008, 44, $3-5$.

25. Chen, W.L.; Qian, Y.; Meng, W.F.; Pang, J.Y.; Lin, Y.C.; Guan, Y.Y.; Chen, S.P.; Liu, J.; Pei, Z.; Wang, G.L. A novel marine compound xyloketal B protects against oxidized LDL-induced cell injury in vitro. Biochem. Pharmacol. 2009, 78, 941-950.

26. Zhao, J.; Li, L.; Ling, C.; Li, J.; Pang, J.Y.; Lin, Y.C.; Liu, J.; Huang, R.; Wang, G.L.; Pei, Z.; et al. Marine compound Xyloketal B protects PC12 cells against OGD-induced cell damage. Brain Res. 2009, 1302, 240-247.

27. Lu, X.L.; Yao, X.L.; Liu, Z.; Zhang, H.; Li, W.; Li, Z.; Wang, G.L.; Pang, J.; Lin, Y.; $\mathrm{Xu}, \mathrm{Z} . ;$ et al. Protective effects of xyloketal B against MPP+-induced neurotoxicity in Caenorhabditiselegans and PC12 cells. Brain Res. 2010, 1332, 110-119.

28. Xu, Z.; Li, Y.; Xiang, Q.; Pei, Z.; Liu, X.; Lu, B.; Chen, L.; Wang, G.; Pang, J.; Lin, Y. Design and synthesis of novel xyloketal derivatives and their vasorelaxing activities in rat thoracic aorta and angiogenic activities in zebrafish angiogenesis screen. J. Med. Chem. 2010, 53, 4642-4653.

29. Krohn, K.; Riaz, M.; Flörke, U. Synthesis of Xyloketals, Natural Products from the Mangrove Fungus Xylaria sp. Eur. J. Org. Chem. 2004, 2004, 1261-1270.

30. Pettigrew, J.D.; Bexrud, J.A.; Freeman, R.P.; Wilson, P.D. Total synthesis of (+/-)-xyloketal D and model studies towards the total synthesis of (-)-xyloketal A. Heterocycles 2004, 62, 445-452.

31. Rodriguez, R.; Adlington, R.M.; Moses, J.E.; Cowley, A.; Baldwin, J.E. A New and Efficient Method for $o$-Quinone Methide Intermediate Generation: Application to the Biomimetic Synthesis of ( \pm -Alboatrin. Org. Lett. 2004, 6, 3617-3619. 
32. Krohn, K.; Riaz, M. Total synthesis of $(+)$-xyloketal D, a secondary metabolite from the mangrove fungus Xylaria sp. Tetrahedron Lett. 2004, 45, 293-294.

33. Pettigrew, J.D.; Freeman, R.P.; Wilson, P.D. Total synthesis of (-)-xyloketal D and its - Confirmation of absolute stereochemistry. Can. J. Chem. 2004, 82, 1640-1648.

34. Pettigrew, J.D.; Wilson, P.D. Synthesis of xyloketal A, B, C, D and G analogues. J. Org. Chem. 2006, 71, 1620-1625.

35. Pettigrew, J.D.; Wilson, P.D. Total synthesis of (-)-xyloketal A. Org. Lett. 2006, 8, 1427-1429.

36. Huang, Y.; Lin, Y.C. Concise Synthesis of Xyloketal C Analogues. Heterocycles 2009, 78, $749-755$.

37. Xu, Z.; Li, Y.; Lu, B.; Pang, J.; Lin, Y. An Expedient Approach to the Benzopyran Core: Application to Synthesis of the Natural Products ( \pm )-Xyloketals and ( \pm )-Alboatrin. Chin. J. Chem. 2010, 28, 2441-2446.

38. Hermann, A.C.; Millard, P.J.; Blake, S.L.; Kim, C.H. Development of a respiratory burst assay using zebrafish kidneys and embryos. J. Immunol. Methods 2004, 292, 119-129.

39. Przedborski, S.; Vila, M. The 1-Methyl-4-Phenyl-1,2,3,6-Tetrahydropyridine Mouse Model. Ann. N. Y. Acad. Sci. 2003, 991, 189-198.

40. Gollnick, K.; Knutzen-Mies, K. Dye-sensitized photooxygenation of 2,3-dihydrofurans: Competing [3 +2$]$ cycloadditions and ene reactions of singlet oxygen with a rigid cyclic enol ether system. J. Org. Chem. 1991, 56, 4017-4027.

(C) 2013 by the authors; licensee MDPI, Basel, Switzerland. This article is an open access article distributed under the terms and conditions of the Creative Commons Attribution license (http://creativecommons.org/licenses/by/3.0/). 